\title{
Örgütsel Stres, Örgütsel Bağlılık ve Öğrenilmiş Güçlülük İlişkisi Üzerine Bir Araştırma ${ }^{1}$
}

\author{
DOI: 10.26466/opus.557530 \\ * \\ Hande Bilgili* - Erol Tekin** \\ * Yüsek Lisans Mezunu,Kastamonu Üniversitesi S.B.E, Sinop / Türkiye \\ E-Posta: bilgilihande@gmail.com ORCID: 0000-0001-9638-2063 \\ ** Dr. Öğr. Üyesi Kastamonu Üniversitesi, İktisadi Bilimler Fakültesi, Kastamonu / Türkiye \\ E-Posta: etekin@kastamonu.edu.tr \\ ORCID: $\underline{0000-0003-1166-7671}$
}

\section{Öz}

Bireyler örgütlerde yaşanan eşitsizlik, rol belirsizliği, zaman baskısı, iş yükünün fazla olması gibi nedenlerden dolayı strese maruz kalabilmektedirler. Örgütlerde yaşanan stres; yöneticiler, çalışanlar ve örgütün çıkarları açısından oldukça önem taşımaktadır. Çünkü makul seviyede stres olumlu etkiler ortaya çıkarmasına rağmen örgütsel stres motivasyon, performans, iş tatmini, iletişim ve örgütsel bağhllık gibi örgütsel konularda çoğu kez olumsuzluklara neden olabilmektedir. Bu bağlamda çalışmanın temel amacl; örgütsel stres, örgütsel bağlllık ve öğrenilmiş güçlülük arasındaki ilişkiyi incelemektir. Bu amaç çerçevesinde kamu üniversitelerinde çalışan 226 öğretim elemanı üzerinde anket çalışması gerçekleştirilmişsir. Toplanan veriler SPSS 23.0 programı ile analiz edilmiştir. Elde edilen verilere faktör, korelasyon ve regresyon analizleleri uygulanarak hipotezler test edilmiştir. Analizler sonucunda; örgütsel stresin örgütsel bağlllığı azalttığı görülmüştür. Ayrıca öğrenilmiş güçlülü̈̆̈̈̈n örgütsel stresi önleme noktasinda etkisinin olduğu bulunmuştur. Son olarak öğrenilmiş güçlülü̈̆̈̈̈n örgütsel bağhllı̆ğ arttırıcı bir etkiye sahip olduğu da tespit edilmiştir. Çalışma örgütsel bağlllık, örgütsel stres ve öğrenilmiş güçlülük kavramların birlikte ele alması açısından yazına katkıda bulumayı hedeflemektedir.

Anahtar Kelimeler: Örgütsel stres, Öğrenilmiş güçlülük, Örgütsel bağlllık

\footnotetext{
${ }^{1}$ Bu çalışma Dr. Öğr. Üyesi Erol TEKIN danışmanlığında Hande BiLGiLi tarafından hazırlanan ve Kastamonu Üniversitesi Sosyal Bilimler Enstitüsü’nce kabul edilen aynı adlı yüksek lisans tezinden türetilmiştir.
} 


\title{
An Investigation of The Relationships between Organizational Stress, Organizational Commitment and Learned Resourcefulness
}

\begin{abstract}
Individuals undergo stress for reasons such as inequality in organizations, role ambiguity, time pressure, workload density etc. Stress encountered in organizations is of capital importance for managers, employees and organization's benefits. However, although reasonable stress creates positive effects, organizational stress often leads to negativity in organizational issues such as motivation, performance, job satisfaction, communication and organizational commitment. In this context, the aim of this study is to investigate the relationship between organizational stress, organizational commitment and learned resourcefulness. Within the scope of this aim, a questionnaire was applied to 291 research assistants and lecturers working at public universities. The collected data were analyzed with SPSS 23.0 program. The obtained data were analyzed by factor, correlation and regression analysis. Results of analysis, organizational stress has been shown to reduce organizational commitment. In addition, it has been determined that the learned resourcefulness has an effect on prevention of organizational stress. Finally, it has also been found that learned resourcefulness has an effect that increases organizational commitment. The study aims to contribute to the literature in terms of combining the concepts of organizational commitment, organizational stress and learned resourcefulness.
\end{abstract}

Keywords: Organizational stress, Organizational commitment, Learned resourcefulness 


\section{Giriş}

Modern hayatın getirisi aşırı stres sadece özel hayatta değil çalışma hayatında da etkisini arttırmaktadır. Uzun vadede ve makul düzeyde stres yapılan işler için motivaston kaynağı olarak görülebilmektedir (Orloff, 2005; Yılmaz ve Ekici, 2010). Fakat örgütler için stres, genellikle tehlike unsuru sayılmakta ve örgüt mekanizmasını olumsuz yönde etkilemektedir (Köknel, 1989; Gökdeniz, 2005). Bunun için stresin yaratacağ1 olumsuz durumların etkilerinin görülmesi ve ortadan kaldırılması için örgütsel bazı konulara eğilmek önem arz etmektedir. Bu noktada örgütsel bağll1ık, örgütün hedeflerine ulaşma yolundaki önemli olgulardan bir tanesidir. Çünkü örgütsel bağlılı̆̆ yüksek olan çalışanlar kendini işine vermekte, örgütün çıkarları ve hedefleri için çalışmaktadırlar. Bunun karşılığında da örgütlere çalışanların iç dünyasını, yaşam kalitesi ve sağlığını koruma görevi düşmektedir. Aslında bu konuda sadece örgütlere görev düşmemektedir. Bir yandan da çalışanın kendisini strese karşı koruması gerekmektedir. Bu durumda öğrenilmiş güçlülük kavramı stresle başa etmede karşımıza çıkmaktadır.

Üniversiteler ekonomi, finans, politika, çevresel sorunlar, sosyal yaşam, kültürel ve teknolojik gelişmeler, bireyler arası ilişkiler, psikoloji gibi birçok konuda tüm dünyayı etkileyebilecek çalışmaları gerçekleştiren global kurumlardır (Ağıralioğlu, 2012). Bu nedenle üniversitelerde makul seviyede stres harici ortaya çıkan yoğun stresin yaratacağı olumsuz durumların düşük seviyede olması beklenmektedir. Makul seviyede olmayan stres; motivasyon sarsıcı, sürekli tetikte olmaya zorlayan, enerji azaltan ve hastalıklara sebep olan bir güce sahip olabilmektedir. Özellikle yüksek düzeyde eğitim veren, bilimsel araştırmalar yapan üniversitelerde önemli bir basamak olan öğretim elemanlarının çeşitli nedenlere bağlı olarak stres düzeylerinin yüksek olduğu dikkat çekmektedir (Korkut, vd., 1994; Bakioğu ve Yaman, 2004; Üzüm vd., 2014; Göksel ve Tomruk, 2016). Kadro sorunu, yetersiz yabancı dil, ekonomik sorunlar, çalışma ortamındaki fiziki yetersizlikler gibi konular başlıca yaşadıkları zorluklar arasındadır (Anıl vd., 2015; Yılmaz ve Şahin, 2016). Bunların yanı sıra araştırma görevlisi ve öğretim görevlisi kadrosunda bulunan akademik personelin iş tanımlarının net olmadığı görülmektedir (Tekin ve Birincioğlu, 2017a). 
Bu durum söz konusu akademik personelin sorumluluklarını daha da arttırmaktadır. Bu sorumluluğu yerine getirmek için ise ilgili öğretim elemanlarının verimli olması ve yaptıkları işin kalitesinin artması gerekmektedir (Tekin ve Birincioğlu, 2017b). Fakat özellikle iş tanımlarındaki bilinmezlik gibi söz konusu akademik personel üzerinde baskı yaratacak unsurlar da stresi ortaya çıkarabilmektedir. Kısacası araştırma görevlilerinin ve öğretim görevlilerinin çalışma koşullarındaki tüm bu zorluklar; bilime katkı sağlayamamalarına, becerilerinin körelmesine ya da becerilerini kullanamamalarına neden olabilmektedir (Yılmaz ve Şahin, 2016).

$\mathrm{Bu}$ kapsamda bilgi toplumunun hedeflerine ilerlemesi için örgütsel bağll1ık düzeyleri yüksek araştırma görevlilerine ve öğretim görevlilerine ihtiyaç vardır. Özellikle örgütsel bağlılığı olumsuz etkileyen stresin, öğrenilmiş güçlülük becerisiyle en aza indirgenmesinin araştırma görevlileri ve öğretim görevlileri açısından oldukça önemli olduğu bir gerçekliktir. Bu nedenle örgütsel stresin getirdiği sorunlar ve bunlarla başa çıabilme noktasındaki eksiklikler örgüt için önemli bir durumdur. Bu bağlamda söz konusu akademik personelin hem stres nedenlerinin ortaya konulması hem de stresle başa çıkma noktasında nasıl davranması gerektiğinin araştırılması; stresin çalışanların örgütsel davranış biçimlerini nasıl etkileyeceğini ortaya koymak, çalışma ortamlarında stresin etkilerinin azaltmak açısından önemli bir husus olarak ifade edilebilir. Bu bağlamda; çalışmada örgütsel stres, öğrenilmiş güçlülük ve örgütsel bağlılık arasındaki ilişki üniversite camiasının önemli paydaşlarından araştırma görevlileri ve öğretim görevlileri açısından ele alınacaktır.

Çalışmanın amacına uygun olarak giriş bölümünü takip eden ilk bölümde kavramsal çerçeveye değinilecektir. Ardından literatüre yer verilerek hipotezler oluşturulacak ve araştırma modeli çizilecektir. Sonrasında araştırmanınamacı, önemi, veri toplama yöntemi, analiz yöntemini içeren araştırma metodolojisi sunulacaktır. Son olarak araştırma bulguları, sonuçlar, tartışma ve öneriler ile çalışma sonlandırılacaktır.

\section{Kavramsal Çerçeve}

Stres; korku, üzüntü, gerilim, kaygı, endişe, kuşku, heyecan gibi duyguların bir aradaki ifadesi olarak açılamakta ve günümüz iş yaşamının ayrılmaz bir parçası olarak görülmektedir (Paşa ve Kaymaz, 2013). Stres, 
genel anlamda; kişinin içinde bulunduğu ortamın ve çalışma hayatındaki şartların etkisiyle bedeninde biyolojik salgılar üreterek, bahsedilen şartlara uyum sağlaması fiziksel ve düşünsel olarak harekete geçmesi hali olarak açıklanır. Birey, güçlüklerle başa çıkmada kendisini yetersiz olarak algilıyorsa ve gerçekleşmesini istediği durumla içinde bulunduğu durum arasında büyük bir fark varsa bu durumda stres meydana gelmektedir. Yani stres; kişinin potansiyeliyle çevresinin ondan yapmasını ümit ettiklerinin örtüşmemesi sonucu ortaya çıkmaktadır. Aynı durum örgüt içinde de görülmektedir. Çalışanın kapasitesi ile örgütün değerleri arasındaki ilişkide negatif yönde fark arttığında stres ortaya çıkmaktadır (Efeoğlu ve Özden, 2007).

Mal veya hizmet üreterek toplumun ihtiyaçlarını karşılayan örgütler, hedefleri doğrultusunda nitelikteki iş gücünü bünyesinde çalıştırmak istemektedirler. Çalışanları, örgütün tüm kaynaklarını birleştiren ve işleyen kişiler olmalıdır. Çünkü örgüt, çalışanların emeği karşılığında bir gelir vererek onların temel ihtiyaçlarını karşılamaktadır. Bu yüzden çalışma ortamındaki stres faktörleri, çalışanın fizyolojik ve psikolojik olarak etkileyeceği için örgütün konusu olmaktadır (Gümüştekin ve Gültekin, 2009). Bu kapsamda insanların psikolojik ve bedensel yapılarında baskı oluşturarak; duygularını, düşüncelerini, davranışlarını, verimliliklerini ve ilişkilerini etkileyen bir uyum süreci olarak açıklanan stres, günümüz çalışma hayatının önemli bir parçasıdır. Stresin hızı ve sürekliliği çalışanlar üzerinde iyi veya kötü sonuçlar doğurduğu mutlaka göz önüne alınıp değerlendirilmelidir (Aydın, 2012). Bu nedenle çalışanların örgüt içinde yaşadığı stres ve bu stresin örgüt içerisindeki tüm çalışanları hatta örgütteki işleyişi etkilenmesi, uzmanların araştırmalarını örgütsel stres üzerine yoğunlaştırmasına neden olmuştur (Işıkhan, 2004).

İş yaşamında bir sorun olan stresin ana faktörü günümüzde çoğunlukla yoğun rekabet ortamı, sosyal ve ekonomik yapıdaki değişim ve teknolojik gelişmeler olarak düşünülebilir. Hayatın her anında insanın stresle karşı karşıya olması, bireyin hem iş yaşantısını hem de günlük yaşantısını olumsuz yönde etkilemektedir. Bu yüzden yaşantımızın bir parçası halini almış olan stresin yönetilmesi önemli hale gelmiştir (Onay ve Kılc1, 2011). Stresin kaynağ 1 genellikle çevresel, bireysel ve örgütsel nedenlerdir. Stres; bireysel farklılıklardan, iş deneyiminden, sosyal çevre koşullarından ortaya çıkmakta ve farklı psikolojik ya da fiziksel sonuçlar 
ortaya çıkarmaktadır (Gümüştekin ve Öztemiz, 2005). Hangi kaynağa dayalı ortaya çıkarsa çıksın stres, çalışanlar üzerindeki baskının şiddetli şekilde artmasına ve buna bağlı olarak çalışanın işten soğuyarak uzaklaşmasına ve örgüt yönünden de verimliliğin giderek düşmesine neden olabilir (Gümüştekin ve Gültekin, 2009). Bu noktada tüm örgütlerin amacının kâr etmek, ayakta kalmak, devamlılıklarını sağlayarak hedeflerini gerçekleştirmek olduğu düşünüldüğünde; örgütler işlerini sahiplenen, güvenilir çalışanlara ihtiyaç duymaktadırlar. Çalışanların bu amaçlara karşı güdülenmesi örgüte bağlılıklarından geçmektedir.

Örgütsel bağlılık, örgüt ve çalışanların amaçlarının aynı yolda ilerlemesine neden olmaktadır. Bu nedenle örgütte bütünlüğün sağlanması son derece önemlidir. Aksi takdirde sadece örgüt değil örgütte çalışan da kazanamayacaktır (Güney, 2011). Günümüzde örgütler verimliliği arttırmak ve maliyeti azaltmak için insan faktörünü öncelikli kullanmalıdır. İnsan faktörünün öncelikli olmasının sebebi amaçlara ulaşmada; bilgili, vasıflı, kolay kavrayabilen çalışanlara sahip olmaktır. Bu nitelikteki çalışanların örgütsel bağlılıklarını sağlamak için çalışanların özel hayatlarındaki ve çalışma hayatlarındaki ihtiyaçlarına gereken önem verilmesi gerekmektedir. Bunlara önem verildiğinde çalışan; örgüt için çalışacak, verimlilik artacak ve maliyet azalabilecektir (Karataş ve Güleş, 2010).

Tüm bunların yanında dünya küreselleşirken, küreselleşmenin etkisi örgütlere de yansımaktadır. Küreselleştirmenin getirdiği değişim hareketiyle teknoloji son hızla ilerlemekte ve işletmeler arası rekabet de artmaktadır. Teknolojinin değişimine ayak uyduran işletmeler kazanmakta, ayak uyduramayanlar ise kaybetmektedir. Artık örgütler rekabet baskısıyla, teknoloji harici örgüt içi faaliyetlerini geliştirmeye başlamışlardır. Yani kendilerine yönelmişler ve stratejileriler geliştirmişlerdir (Öğüt vd., 2004). Aslında örgütsel bağlılık sağlama da bu stratejilerden bir tanesi olarak ifade edilebilir.

Yazın incelendiğinde örgüte bağlılık gösteren çalışanların, verimli oldukları ve güçlü sorumluluk duygularının olduğu görülebilir. Örgütsel bağlılığı yüksek olan çalışanlar işi bırakma ve işe devamsızlık gibi örgütü zarara uğratacak davranışlardan kaçınarak örgüte daha sadık bireyler haline gelmektedirler. $\mathrm{Bu}$ sadakat sayesinde örgütün maliyetlerinin düşmesi, örgüte büyük ölçüde avantaj sağlamakta ve hem örgüt hem de çalışan kazanabilmektedir (Yazıcıoğlu ve Topaloğlu, 2009). 
Yapılan araştırmalarda çoğu araştırmacı örgütsel bağlllı̆̆n önemine değinmiştir (Porter vd., 1974; Allen ve Meyer, 1991; Doğan ve Kılıç, 2007; Janssen, 2004; Koç, 2009). Bu nedenle örgütsel bağlllığın örgüt ile ilgili diğer kavramları üzerindeki etkileri araştırılarak, farklı değişkenlerle ilişkisini inceleyen birçok çalışma yürütülmüştür. Örgütsel bağlllığın; çalışma davranışına, işten ayrılmaya, iş doyumuna, performansa, kurumsal kimliğe, dürüstlük ve fedakârlık gibi örgüt vatandaşlığı davranış kavramlarına etkisi bu araştırmaların önem kazanmasına neden olmuştur (Tiryaki, 2005). Bu nedenlerden dolayı örgütsel bağlılık kavramı, mal veya hizmet üretmek kadar önemli görülmektedir (Çöl, 2004). Çünkü örgütlerin en önemli unsuru olan insan faktörüne verilen özen, çalışanın örgütte daha fazla kalmasını ve verimliliğin arttırmasını sağlayacaktır (Topaloğlu vd., 2008). Bu yüzden de stresin azaltılması ve çalışanların örgütlerin daha çok sahiplenmesinin sağlanması önem arz etmektedir. Bu kapsamda karşımıza öğrenilmiş güçlülük denen ve örgütsel stresi minimize etme noktasında oldukça önemli olan bir kavram çıkmaktadır. Çünkü öğrenilmiş güçlülük düzeyi yüksek bireylerin stres ile başarılı bir şekilde başa çıkabilmeleri daha muhtemel ve mümkündür.

Öğrenilmiş güçlülük; bireyin davranışlarını denetleyen, iç dünyasını şekillendiren bilişsel beceridir. İç dünyayı oluşturan, iç dünyayı davranışlara dökmemizi sağlayan duygular; acl, keder, arzu, sevinç, kuvvet gibi hislerdir. $\mathrm{Bu}$ hislerin bireyde yarattığı etkileri kontrol altına alma görevini öğrenilmiş güçlülük becerisi sağlamaktadır. Bireyler öğrenilmiş güçlülük becerisini yaşam boyu geliştirerek stresle baş etmede kullanmaktadır (Rosenbaum ve Jaffe, 1983). Ayrıca iç dünya hislerinin etkisini ve istenmeyen durumların en aza indirgenmesini öğrenilmiş güçlülükle sağlanabilmektedir (Özkan ve Yıldız, 2015).

Öğrenilmiş güçlülük; strese karşı gösterilen başa çıkma, inanç, beceri ve öz kontrol davranışlarının toplamı olarak tanımlanmaktadır (Rosenbaum, 1990). İçsel duyguların etkisiyle istenilen davranış sergilemek için sadece inanmak yeterli olmamaktadır. İstenilen davranışı sergilemek için beceri de gerekmektedir. Bu becerilerin tümü bireyin öğrenilmiş güçlülük davranış repertuvarlarını oluşturur. Davranış repertuvarı sadece bir kişinin içsel dünyasıyla oluşan hislerle şartlanmayla oluşmamakla birlikte öğrenme ve eğitim yoluyla da kazanılabilir (Rosenbaum ve Jaffe, 1993). 
Öğrenilmiş güçlülük seviyesi bireyden bireye değişmektedir. Bunun sebebi bireylerin farklı hayat tecrübelerine sahip oluşudur. Stres kaynakları karşısında; öğrenilmiş güçlülük düzeyi yüksek olan bireyler, öğrenilmiş güçlülük düzeyleri düşük olan bireylere göre daha güçlüdür. Öğrenilmiş güçlülük düzeyi yüksek olan bireyler stresle mücadele de daha savaşçı ruhludur (Rosenbaum, 1980). Bu bireyler stresle baş etmede, kararlı ve dirençli davranarak hedeflere ulaşmada mücadele etmektedirler. Öğrenilmiş güçlülük düzeyi düşük bireyler ise stresle baş etmede beceriksiz olduklarını kabul ederek mücadeleden kaçınmaktadırlar (Yürür ve Keser, 2010).

Bunlarla birlikte örgütlerde, örgütsel bağl1lı̆̆1 etkileyen faktörler göz önüne alındığında öğrenilmiş güçlülük becerisinin önemi ortaya çıkmaktadır. Örgütsel bağlılık, kişisel ve örgütsel faktör etkilerinden oluşmaktadır. Örgütsel bağlılık seviyesi; ödüller, kariyerde ilerleme olanağı̆, iş tatmini gibi etmenler ve öğrenilmiş güçlülük etkileşimiyle belirlenmektedir (Yıldız, 2014). Yani örgütsel bağlılığı sağlayacak kaynakların gerçekleşmemesi durumunda çalışanda oluşan stres ve memnuniyetsizlik öğrenilmiş güçlülük becerisi ile şekillendirilebilir. Öğrenilmiş güçlülük becerisi ile şekillenmiş örgütsel stres ve bununla birlikte örgütsel bağlllık; verimli, sağlıklı ve mutlu çalışanların örgüte kazandırılmasını sağlayabilir (Çınar vd., 2016).

Tüm bu açıklamalar çerçevesinde örgütsel stres ve örgütsel bağlılık arasındaki ilişkiyi ele alan çalışmalara yazında rastlamak mümkündür. Fakat özellikle stresin etkilerinin en aza indirilmesi hususunda öğrenilmiş güçlülük kavramını ele alan çok fazla çalışmaya rastlamak mümkün değildir. Bu bağlamda çalışmada örgütsel stres, örgütsel bağlllık ve öğrenilmiş güçlülük arasındaki ilişkinin incelenmesi özellikle örgütsel yazında oldukça önemli olan örgütsel bağlılığın arttırılması için yapılacakların daha iyi anlaşılmasına ışık tutabilecektir.

\section{Literatür Taraması ve Hipotezler}

Yerli ve yabancı yazında; örgütsel stres ile örgütsel bağlılık ilişkisi sıklıkla araştırıldığı görülmekte iken son zamanlarda dikkat çeken bir konu olan öğrenilmiş güçlülük ile örgütsel stres ve örgütsel bağlllık ilişkisinin daha az çalışmada incelendiği söylenebilir. Örgütsel bağl1lık ile örgütsel stres 
arsındaki ilişkiyi ele alan çalışmalara bakıldığında; Bateman ve Strasser (1984), Amerika'da bir güney şehrinin 4 hastanesinde bulunan 129 hemşire üzerinde örgütsel bağlılığın öncüllerini belirlemek için yaptıkları araştırmada; örgütsel bağlllık ile iş gerilimi arasında negatif ilişki tespit etmişlerdir.

Yılmaz ve Ekici (2003), Sivas'ta Karayolları 16. Bölge Müdürlügünde ve bölgeye bağlı şube ve şantiyelerde görev yapan 156 çalışan üzerinde mesleki stresin bireysel ve örgütsel sonuçlarını belirlemek için yaptığ1 araştırmalarında; aşırı olmayan stresin çalışan motivasyonunu arttırdığ ve örgütsel bağlılık ögelerinden olan verimliliği arttırdığını tespit etmişlerdir.

Gül vd. (2008), Tokat Devlet Hastanesi'nde görevli 87 sağlik personeli üzerinde iş tatmini, stres ve örgütsel bağlllık ile işten ayrılma niyeti ve performans arasındaki ilişkiyi incelemek için yaptıkları araştırmada; iş stresi ile örgütsel bağlllık arasında önemli davranışsal ilişkiler olduğunu belirtmişlerdir.

Viljoen ve Rothmann (2009), Güney Afrika'da bir üniversitede 353 akademik personel üzerinde örgütsel stres, hastalık ve örgütsel bağlılık ilişkisini incelemek için yaptıkları araştırmada, örgütsel bağlılık ile örgütsel stres arasında negatif ilişki tespit etmişlerdir.

Şahin (2014), İstanbul'da bulunan 269 turizm acentesinde çalışanlar üzerinde seyahat işletmelerinde örgütsel stres ile çalışanın örgütsel bağllıkları arasındaki ilişkinin tespiti için yaptığı araştırmada; örgütsel stres algılamaları ile örgütsel bağlılıkları arasında anlamlı bir ilişki bulamamiş.

Bhatti vd. (2016), Pakistan'da 3 farklı bankada 30 banka çalışanı üzerinde iş stresinin bankacılık sektöründe örgütsel bağlılık üzerindeki etkisini belirlemek için yaptıkları araştırmada; stresin çalışanın organizasyona olan bağlılığını azaltan önemli bir neden olduğunu belirtmişlerdir.

Bu kapsamda yazın çerçevesinde ve çalışmanın amacına uygun olarak aşağıdaki hipotezler geliştirilmiştir.

- $H_{1}$ : Örgütsel stres örgütsel bağlllığı ve alt boyutlarını (H1a: duygusal bağl1lığı; $H_{1 b}$ : devam bağlılığını; $H_{1 c}$ : normatif bağlılı̆̆1) etkilemektedir. 
Yazın incelendiğinde öğrenilmiş güçlülük ile örgütsel stres ve örgütsel bağlılık ilişkisini ele alan az sayıda çalışmaya ratlanmasına rağmen son yıllarda yapılan çalışmalrın var olduğu görülmektedir. Bu çalışmalara bakıldığında; Rosenbaum ve Cohen (1999), İsrail'de 94 çalışan evli kadın üzerinde aile-çalışma çatışmasının üzüntü düzeylerine etkisi belirlemek için yaptıkları araştırmada; kadınların birden fazla rolle başa çıkmaya yönelik öz-kontrol becerilerine sahip olup olmadıklarını ölçerek, öğrenilmiş güçlülük seviyesi düşük olan kadınların eşlerinden destek almaları durumda daha az stres yaşadıklarını tespit etmişlerdir.

Akgün ve Ciarrochi (2003), Avustralya Wollongong Üniversitesi birinci sınıf 141 lisans öğrencisi üzerinde, akademik stres ve öğrenilmiş güçlülük düzeylerini belirlemek için yaptıkları araştırmada; stresin, öğrenilmiş güçlülük düzeyi düşük olan öğrencilerin notlarını olumsuz yönde etkilediğini, ancak öğrenilmiş güçlülük düzeyi yüksek düzeyde olan öğrenciler üzerinde hiçbir etkiye sahip olmadığını tespit etmişlerdir.

Kennett ve Keefer (2006), Trent, Peterborough ve Ontario Üniversiteleri'nde 224 öğrenci üzerinde öğrenilmiş güçlülük ile zekâ seviyesi ve akademik başarı ilişkisini incelemek için yaptıkları araştırınarmada, öğrenilmiş güçlülük düzeyi düşük olanların stres ve akademik başarısızlık yaşadığını tespit etmişlerdir.

Yıldırım vd. (2012), Aksaray Üniversitesi'ndeki akademisyenler üzerinde öğrenilmiş güçlülüğün alt boyutları ile iş stresi alt boyutları arasında ilişki anlamak amacıyla yaptıkları çalışmada; öğrenilmiş güçlülüğün 2 alt boyutu (erteleme, istenmeyen düşüncelerin denetimi) ile iş stresinin 2 alt boyutu (baskı ve aşırı yüklenme) arasında pozitif yönlü zayıf bir ilişki olduğunu tespit etmişlerdir.

Çakır (2014), İstanbul'da kamu hastanelerinde çalışan 383 sağlık personeli üzerinde, öğrenilmiş güçlülük ve stresle başa çıabilme arasındaki ilişkiyi belirlenmek için yaptığı araştırmada; öğrenilmiş güçlülük düzeyleri yüksek olan sağlık personelinin stresle başa çıkabilme becerisinin yüksek olduğunu belirtmiştir. Öğrenilmiş güçlülük ile stresle başa çıkma yetisinin arasındaki ilişkinin anlamlı olduğunu belirlemiş ve öğrenilmiş güçlülük ile stresle başa çıma kavramsal boyutunun bileşeni konumundaki iyimser yaklaşım ile arasındaki ilişkiyi anlamsız bulmuştur. 
Çınar vd. (2016), İstanbul'da 350 sağlık personeli üzerinde öğrenilmiş güçlülük ile işten ayrılma niyetleri arasındaki ilişkiyi belirlemek için yaptıkları araştırmada; örgütsel bağlılık düzeylerinin duygusal anlamda öğrenilmiş güçlülük ile ilişkili olduğu ve bu ilişkinin yüksek olduğu tespit etmişlerdir.

Çetin (2018), Kapadokya bölgesinde faaliyet gösteren dört ve beş yıldızlı otellerde çalışanlar üzerinde öğrenilmiş güçlülük ile iş stresi ilişkisi algılanan sosyal desteğin rolünü belirlemek için yaptığı çalışmada; öğrenilmiş güçlülük ve örgütsel stres araında negatif yönde anlamlı bir ilişki tespit etmiştir.

Yazın incelendiğinde öğrenilmiş güçlülüğün hem örgütsel stresi olumsuz yönde etkileyerek azaltabileceği hem de örgütsel bağlılı̆̆ı arttıracağı düşüncesinden yola çıkılarak aşağıdaki hipotezler geliştirilmiştir.

- $H_{2}$ : Öğrenilmiş güçlülük örgütsel bağlılığ ve alt boyutlarını $\left(H_{2 a}\right.$ : duygusal bağlılığ1; $H_{2 b}$ : devam bağl1lı̆̆ını; $H_{2 c}$ : normatif bağlılığ1) etkilemektedir.

- $\quad H_{3}$ : Öğrenilmiş güçlülük örgütsel stresi etkilemektedir.

Yazın taraması sonucunda özellikle yüksek öğretim camiası içerisinde akademik yükselmenin ilk adımları olan araştırma görevliliği ve öğretim görevliliği kadrosunda bulunan akademik personelin örgütsel stres, bağllık ve öğrenilmiş güçlülük düzeyleri ortaya konularak öğrenilmiş güçlülük, örgütsel stres ve örgütsel bağlllık arasındaki ilişkiyi ele almayı amaçlayan çalışmanın kavramsal modeli Şekil 1'de görülebilmektedir.

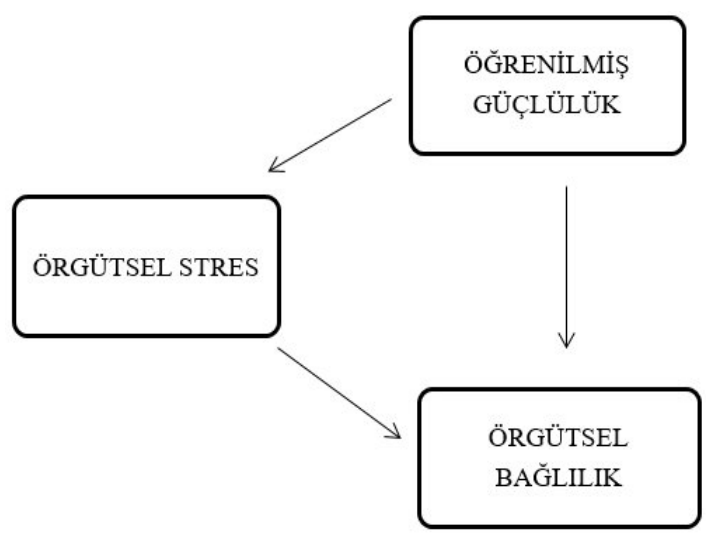

Şekil 1. Araştırmanın Kavramsal Modeli 


\section{Araştırma Metodolojisi}

\section{Evren ve Örneklem}

Araştırmanın evrenini Karadeniz Bölgesi'nde yer alan kamu üniversitelerinde görev yapan araştırma görevlileri ve öğretim görevlileri oluşturmaktadır. Bu noktada anketlerin uygulanabilmesi için izin alınması gereken üniversitelerden izin alınmış, gönüllü katılımcılar içinde sadece anket linki yollanmıştır. Kullanılan anket linki kaynakçada yer almaktadır. Veri toplama işleminin ardından eksiksiz cevaplanan 226 anket elde edilmiştir. Bu kapsamda çalışmanın örneklemini; 163'ü araştırma görevlisi, 63'ü öğretim görevlisi olmak üzere toplam 226 öğretim elemanı oluşturmaktadır.

\section{Veri Toplama Aracı ve Analiz Yöntemi}

Hazırlanan anket formu dört bölümden oluşmaktadır. İlk bölümde katılımcıların; unvan, cinsiyet, öğrenim aşaması, yaş, deneyim gibi özelliklerini belirlemeye yönelik demografik sorular yer almaktadır. İkinci bölümde örgütsel stres düzeylerini belirlemeye yönelik sorular sorulmuştur. Üçüncü bölümde katılımcıların örgütsel bağlılık düzeylerini ölçen sorular bulunmaktadır. Son bölümde ise öğrenilmiş güçlülüğe ilişkin sorulara yer verilmiştir.

Çalışanların iş stresi düzeylerinin belirlenmesi için Dr. Suzanne Haynes tarafından Ulusal Sağlık İstatistikleri Merkezi'nde çalışan kadınlar ile erkekler üzerinde uygulanarak geliştirilen ve Aktaş (1996) tarafından uyarlanan 10 soruluk iş stresi ölçeği kullanılmıştır. Örgütsel bağlılık düzeylerinin belirlenmesi için Allen ve Meyer (1990) tarafından geliştirilen ve akademisyenlere yönelik uyarlaması Tekin ve Birincioğlu (2017a) tarafından yapılan anket kullanılmıştır. Çalışanların öğrenilmiş güçlülük düzeylerinin belirlenmesi için Rosenbaum (1980) tarafından geliştirilen ve Türkçe'ye uyarlaması Siva (1991) ve Dağ (1991) tarafından yapılan 36 soruluk öğrenilmiş güçlülük ölçeği kullanılmıştır. Tüm anketler 5'li Likert tipinde hazırlanmıştır. Elde edilen veriler SPSS 23.0 programı ile analiz edilmiştir. Veriler analiz edilirken tanımlayıcı istatistikler, 
faktör analizleri ile birlikte korelasyon ve regresyon analizleri kullanılmıştır.

\section{Bulgular}

Çalışmaya katılan 226 kişinin demografik özellikleriyle ilgili bulgular Tablo 1'de özetlenmiştir.

Tablo 1. Katılımcılara İlişkin Tanımlayıcı Bulgular

\begin{tabular}{lll}
\hline Değişkenler & Frekans & Yüzde (\%) \\
\hline Cinsiyet & 110 & 48,7 \\
Erkek & 116 & 51,3 \\
\hline Yadın & Frekans & Yüzde (\%) \\
\hline $22-26$ & 33 & 14,6 \\
$27-31$ & 87 & 38,5 \\
$32-36$ & 74 & 32,7 \\
$37-41$ & 21 & 9,3 \\
42 ve üstü & 11 & 4,9 \\
\hline Öğrenim & Frekans & Yüzde (\%) \\
\hline Lisans & 8 & 0,5 \\
Yüksek Lisans Ders & 13 & 5,8 \\
Yüksek Lisans Tez & 26 & 11,5 \\
Doktora Ders & 38 & 16,8 \\
Doktora Tez & 107 & 47,3 \\
Doktora Mezun & 34 & 15,0 \\
\hline Unvan & Frekans & Yüzde (\%) \\
\hline Araştırma Görevlisi & 163 & 72,1 \\
Öğretim Görevlisi & 63 & 27,9 \\
\hline Medeni Durum & Frekans & Yüzde (\%) \\
\hline Evli & 123 & 54,4 \\
Bekar & 103 & 45,6 \\
\hline Toplam & $\mathbf{2 2 6}$ & $\mathbf{1 0 0}$ \\
\hline
\end{tabular}

Araştırmaya katılanların 116 'sı (\% 51,3) kadın, 110'u (\% 48,7) erkektir. 22-26 yaş arasında 33 (\% 14,6), 27-31 yaş arasında 87 (\% 38,5), 32-36 yaş arasında 74 (\% 32,7), 37-41 yaş arasında $21(\% 9,3)$ ve son olarak 42 yaş ve üzeri $11(\% 4,9)$ kişi olduğu tespit edilmiştir. Çalışmada öğrenim durumuna göz atıldığında yüzde oranları \% 3,5 - \% 47,3 arasında değiştiği, 
çoğunluğu doktora tez 107 (\% 47,3) olduğu tespit edilmiştir. Çalışmaya katılanların 123 (\% 54,4)'ü evli, 103 (\% 45,6)'sının bekar olduğu görülmektedir. Son olarak çalışmaya katılan araştırma görevlisi sayısı 163 $(\% 72,1)$ ve öğretim görevlisi sayısı ise $63(\% 27,9)$ olarak ifade edilebilir.

Faktör analizine başlamadan önce örneklemin yeterliliğini test etmek için gözlenen ile kısmi korelasyon katsayılarının büyüklüğünü karşılaştıran bir değer olan KMO test ölçütü incelenmiştir. KMO değerinin 0,50'nin üzerinde olması örneklemin yeterli olduğu kanaati için yeterlidir. Ayrıca KMO oranı ne kadar yüksekse veri seti faktör analizi için o kadar iyidir (Kalayc1, 2010).

Örgütsel stres ölçeği için çıan KMO örneklem yeterliliği değeri 0,894 ile çok iyi şeklinde değerlendirilmektedir. Örgütsel bağllık ölçeği için çıkan KMO örneklem yeterliliği değeri 0,874 ile iyi olarak değerlendirilmektedir. Öğrenilmiş güçlülük ölçeği için çıkan KMO örneklem yeterliliği değeri ise 0,905 ile mükemmel olarak değerlendirilmektedir. Ayrıca tüm ölçekler için; Barlett's küresellik testi sonucuna göre değişkenler arasında anlamlı korelasyon ilişkisi olduğu $(\mathrm{p}=0,000)$ görülmüştür. $\mathrm{Bu}$ bulgular ışığında faktör analizlerine geçilmiştir. Araştırmada kullanılan ölçeklere ilişkin faktör analiz sonuçları Tablo 2, Tablo 3 ve Tablo 4'te özetlenmektedir. Bu kapsamda örgütsel stres ölçeğine ilişkin faktör analiz bulguları Tablo 2'de görülmektedir.

Tablo 2. Örgütsel Stres Ölçeğine Ilişkin Faktör Analizi Bulguları

\begin{tabular}{lc}
\hline $\begin{array}{l}\text { Örgütsel Stres Ölçeği }(\boldsymbol{\alpha = 0 , 9 3 0 ) ;} \text { Toplam Açılanan Varyans: }(\mathbf{\% 6 1 , 7 8 6 ) ;} \text { KMO: } \\
\mathbf{( 0 , 8 6 5 )}\end{array}$ \\
\hline Soru 1 &, 850 \\
Soru 2 &, 803 \\
Soru 3 &, 804 \\
Soru 4 &, 774 \\
Soru 5 &, 746 \\
Soru 6 &, 842 \\
Soru 7 &, 816 \\
Soru 8 &, 800 \\
Soru 9 &, 628 \\
Soru 10 &, 774 \\
\hline
\end{tabular}


Tablo 2'de örgütsel stres ölçeği tek faktör altında toplanmış olup; ölçekte yer alan sorular toplam varyansın \% 61,786'sını açıklamaktadır. Ölçeğin geneline ait güvenilirlik analizleri sonucu ortaya çıkan $\alpha$ değeri 0,930'dur. Bu bulgular çerçevesinde ölçeğin güvenilir olduğu ifade edilebilir. Örgütsel bağlılık ölçeğine ilişkin faktör analiz bulguları Tablo 3'te görülmektedir.

Tablo 3. Örgütsel Bağlılık Ölçeğine Ilişkin Faktör Analizi Bulgularn

\begin{tabular}{|c|c|}
\hline \multicolumn{2}{|c|}{$\begin{array}{l}\text { Örgütsel Bağlılık Ölçeği }(\alpha=0,881) \text {;Toplam Açıklanan Varyans: (\%58,906); KMO } \\
(0,865)\end{array}$} \\
\hline Duygusal Bağlılık: $(\alpha=0,890)$; Açıklanan Varyans: $(\%$ 22,930) & $\begin{array}{l}\text { Faktör } \\
\text { Yükü }\end{array}$ \\
\hline Soru 1 & ,714 \\
\hline Soru 2 & ,772 \\
\hline Soru 3 & 836 \\
\hline Soru 4 & ,823 \\
\hline Soru 5 & 636 \\
\hline Soru 6 & ,736 \\
\hline Devam Bağlılığı: $(\alpha=0,874)$; Açıklanan Varyans: $(\% 20,868)$ & $\begin{array}{l}\text { Faktör } \\
\text { Yükü }\end{array}$ \\
\hline Soru 7 & 645 \\
\hline Soru 8 & ,752 \\
\hline Soru 9 & 795 \\
\hline Soru 10 & 713 \\
\hline Soru 11 & 696 \\
\hline Soru 12 & ,780 \\
\hline Normatif Bağlılık: $(\alpha=0,747)$; Açıklanan Varyans: $(\% 15,107)$ & $\begin{array}{l}\text { Faktör } \\
\text { Yükü }\end{array}$ \\
\hline Soru 14 & 613 \\
\hline Soru 15 & 641 \\
\hline Soru 16 & 711 \\
\hline Soru 17 & 689 \\
\hline Soru 18 & ,584 \\
\hline Soru 19 & ,709 \\
\hline
\end{tabular}

Tablo 3'te görüldüğü üzere örgütsel bağlllık ölçeğine ilişkin sorular 3 boyut altında toplanmıştır. Bu boyutlar duygusal bağlılık, devam bağl1lı̆̆1 ve normatif bağlllık olarak ifade edilmektedir. Orijinal ölçekte yer alan ve devam bağllı̆̆g altında görünen 13. soru faktör analizi sonucunda 
ölçekten çıkarılmıştır. Son haliyle ölçek devam bağlılığ 6 , duygusal bağlılık 6 ve normatif bağlılık 6 soru olmak üzere toplam 18 sorudan oluşmaktadır. Normatif bağlılı̆̆ına ilişkin faktör yüklerinin 0,584 ile 0,711 arasında; devam bağlllık boyutuna ilişkin faktör yükelrinin 0,645 ile 0,795 arasında ve duygusal bağlllık boyutuna ilişkin faktör yüklerinin 0,636 ile 0,836 arasında değiştiği görülmektedir. Ayrıca bu faktörler toplam varyanasın \% 58,906'sını açıklamaktadır. Bununla birlikte güvenilirlik analizleri sonucu ortaya çıan $\alpha$ değerlerinin duygusal bağlılıkta 0,890; devam bağlllığında 0,874 ve normatif bağlllıkta 0,747 olduğu bulunmuştur. Ölçeğin geneline ait değerin ise 0,881 olduğu ifade edilebilir. Bu sonuçlar ölçeğin ve alt boyutlarının güvenilirliğinin yüksek olduğunu göstermesi açısından önemlidir. Öğrenilmiş güçlülük ölçeğine ilişkin faktör analiz bulguları Tablo 4 'te görülmektedir.

Tablo 4. Öğrenilmiş Güçlülük Ölçeğine İlişkin Faktör Analiz Bulguları

\begin{tabular}{|c|c|}
\hline \multicolumn{2}{|c|}{$\begin{array}{l}\text { Öğrenilmiş Güçlülük }(\alpha=0,935) \text {; Toplam Açılanan Varyans: }(\% \text { 80,203); } \\
\text { KMO=(0,905) }\end{array}$} \\
\hline Dürtü Denetimi: $(\alpha=0,845)$; Açılklanan Varyans: $(\% 9,700)$ & Faktör Yükü \\
\hline Soru 1 & 714 \\
\hline Soru 2 & 820 \\
\hline Soru 3 & 709 \\
\hline Yeterlilik: $(\alpha=0,873)$; Açılklanan Varyans: $(\% 8,844)$ & Faktör Yükü \\
\hline Soru 4 & 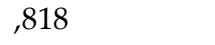 \\
\hline Soru 5 & 763 \\
\hline Soru 6 & 666 \\
\hline Denetleyici Arama: $(\alpha=0,795)$; Açıklanan Varyans: $(\% 8,824)$ & Faktör Yükü \\
\hline Soru 7 & 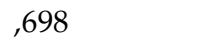 \\
\hline Soru 8 & 806 \\
\hline Soru 9 & ,845 \\
\hline Yatıştırma: $(\alpha=0,755)$; Açıklanan Varyans: $(\% 8,478)$ & Faktör Yükü \\
\hline Soru 10 & 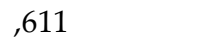 \\
\hline Soru 11 & ,764 \\
\hline Soru 12 & ,515 \\
\hline İyiye Yorma: $(\alpha=0,871)$; Açılanan Varyans: $(\% 7,738)$ & Faktör Yükü \\
\hline Soru 13 & 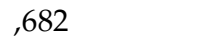 \\
\hline Soru 14 & 490 \\
\hline Soru 15 & ,587 \\
\hline Soru 16 & ,724 \\
\hline
\end{tabular}




\begin{tabular}{|c|c|}
\hline Ruh Hali Denetimi: $(\alpha=0,896)$; Açıklanan Varyans: $(\% 7,373)$ & Faktör Yükü \\
\hline Soru 17 & 729 \\
\hline Soru 18 & ,884 \\
\hline Soru 19 & ,864 \\
\hline Planlı Davranma: $(\alpha=0,828)$; Açıklanan Varyans: $(\% 7,321)$ & Faktör Yükü \\
\hline Soru 20 & ,533 \\
\hline Soru 21 & 822 \\
\hline Soru 22 & 789 \\
\hline Erteleme: $(\alpha=0,837)$; Açıklanan Varyans: $(\%$ 6,269) & Faktör Yükü \\
\hline Soru 23 & 686 \\
\hline Soru 24 & ,761 \\
\hline Soru 25 & ,606 \\
\hline Ağrı Denetimi: $(\alpha=0,823)$; Açıklanan Varyans: $(\%$ 6,006) & Faktör Yükü \\
\hline Soru 26 & 829 \\
\hline Soru 27 & 677 \\
\hline Yardım Arama: $(\alpha=0,748)$; Açıklanan Varyans: $(\% 5,705)$ & Faktör Yükü \\
\hline Soru 28 & 878 \\
\hline Soru 29 & ,836 \\
\hline $\begin{array}{l}\text { İstenmeyen Düş. Denetimi: }(\alpha=0,532) ; \text { Açıklanan Varyans: }(\% \\
3,945)\end{array}$ & Faktör Yükü \\
\hline Soru 30 & 816 \\
\hline Soru 31 &, 520 \\
\hline
\end{tabular}

Tablo 4'e göre, çalışmada oluşan alt boyutlar Dağ (1991) tarafından gerçekleştirilen çalışmadan farklılaşmıştır. Bu çalışma kapsamında 11 alt boyut bulunmuştur. Ortaya çıan boyutlar Kartal ve Gemlik (2018) çalışmasıyla benzerdir. Bu boyutlar dürtü denetimi, yeterlilik, denetleyici arama, yatıştırma, iyiye yorma, ruh hali denetimi, planlı davranma, erteleme, ağrı denetimi, istenmeyen düşünce denetimi, yardım arama olup bu çalışmada alt faktörler kullanılmamış ve yazın dikkate alınarak ölçeğin tümü değerlendirmeye tabi tutulmuştur (Biricik, 2018; Akdeniz, 2018; Çetin, 2018). Ölçeğin geneline ait güvenilirlik analizleri sonucu ortaya çıkan $\alpha$ değeri 0,935 ile güvenilirdir. Güçlülük ölçeğindeki ilgili maddelerden çalışamadaki 28, 29, 8, 30, 31, 7, 9, 12 ve 23. sorular ters puanlanmıştır ve $32,33,34,35$ ve 36 . sorular öğrenilmiş güçlülük ölçeğinden çıkartılmıştır. Değişkenlerin tanımlayıcı istatistikleri ve normallik dağılımına ilişkin bulgular tablosu Tablo 5 'te özetlenmektedir 
Tablo 5. Değişkenlerin Tanımlayıcı Bulguları

\begin{tabular}{llllllll}
\hline Değişkenler & N & Min. & Mak. & Ort. & SS & Çarpıklık & Basıklık \\
\hline Örgütsel Stres & 226 & 1,00 & 5,00 & 3,07 & 0,934 & 0,028 & $-0,569$ \\
Duygusal Bağlllık & 226 & 1,00 & 5,00 & 3,13 & 0,900 & $-0,226$ & $-0,389$ \\
Devamlı Bağlllık & 226 & 1,00 & 5,00 & 3,16 & 0,767 & $-0,205$ & 0,509 \\
Normatif Bağlılık & 226 & 1,00 & 5,00 & 2,76 & 0,917 & $-0,068$ & $-0,303$ \\
Örgütsel Bağlllık & 226 & 1,00 & 4,89 & 3,02 & 0,661 & $-0,112$ & 0,493 \\
Öğgrenilmiş Gü̈clüllük & 226 & 1,00 & 5,00 & 2,99 & 0,698 & 0,036 & 0,49 \\
\hline
\end{tabular}

Çalışmada kullanılan değişkenlerden örgütsel stres boyutu 3,07 ortlamaya sahiptir. Örgütsel bağlılığın; duygusal bağlılık boyutunun 3,13; devam bağlılığ1 boyutunun 3,16; normatif bağlılık boyutunun ise 2,76 ortalamaya sahip olduğu gözlemlenmiştir. Örgütsel bağlllığın genelinin ortalamaası ise 3,02 olarak tespit edilmiştir. Öğrenilmiş güçlüğün oratalaması da 2,99 olarak belirlenmiştir.

Özellikle sosyal bilimlerde normallik varsayımı çarpıklık ve basıklık katsayılarına bakılarak incelenebilir. George ve Mallery'e (2010) göre çarpıklık (skewness) ve basıklık (kurtosis) değerlerinin - 2 ile +2 aralığında yer alması verilerin normal dağıldığını göstermektedir. Tabachnick ve Fidell (2012) ise, bu değerleri $-1,5$ ile $+1,5$ aralığında olduğu durumlarda veri setinin normal dağıldığını kabul etmektedirler. Araştırmada ele alınan değişkenlerin bu varsayımları sağladığı görülmektedir. $\mathrm{Bu}$ durumda verilerin normal dağılıma uygun olduğu söylenebilir.

$\mathrm{Bu}$ bulguların ardından; değişkenler arasındaki ilişkinin varlığı araştırmak için kolerasyon analizine, hipotezlerin testini gerçekleştirmek için regresyon analizlerine geçilmiştir. Anket formunda kullanılan değişkenlerin birbirleri ile olan ilişkilerini görmek amaciyla pearson korelasyon katsayılarından yararlanılmış ve bulgular Tablo 6'da sunulmuştur.

Tablo 6. Korelasyon Analiz Bulgularn

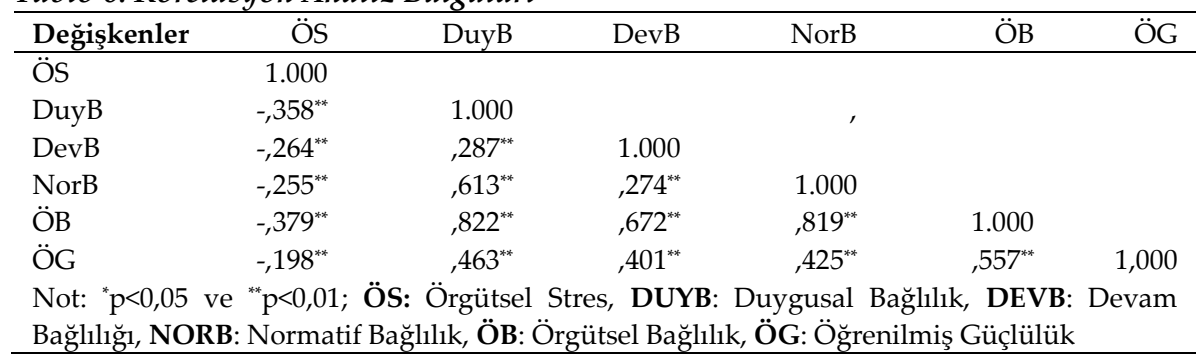


Tablo 6'daki sonuçlara göz atıldığında katılımcıların örgütsel stres ile örgütsel bağlılık arasında negatif yönde ve anlamlı ilişki vardır ( $\mathrm{r}=-, 379$; $p=, 000)$. Benzer şekilde örgütsel stres ile öğrenilmiş güçlülük arasında da negatif yönlü ve anlamlı ilişki tespit edilmiştir ( $\mathrm{r}=-, 198 ; \mathrm{p}=, 000)$. Son olarak örgütsel bağlllık ile öğrenilmiş güçlülük arasında pozitif yönlü ve anlamlı ilişki olduğu sonucuna varılmıştır $(r=, 557 ; p=, 000)$. Korelasyon analizleri sonrasında araştırma hipotezlerinin testine ilişkin regresyon analizlerine geçilmiştir. Bu kapsamda örgütsel stresin örgütsel bağlılık ve alt boyutları üzerindeki etkisini ortaya koyan analiz bulguları Tablo 7' de sunulmuştur.

Tablo 7. Örgütsel Stres ve Örgütsel Bağhllık İlişkisine Yönelik Regresyon Analizleri

\begin{tabular}{|c|c|c|c|c|c|c|c|c|}
\hline \multicolumn{5}{|c|}{ Model Özeti } & \multicolumn{4}{|c|}{ Katsayılar } \\
\hline & \multicolumn{8}{|c|}{ Bağımlı Değişken: Duygusal Bağlılık } \\
\hline & $\mathbf{R}^{2}$ & Düz. $\mathbf{R}^{2}$ & $\mathbf{F}$ & $\mathbf{p}$ & B & $\mathrm{T}$ & $\mathbf{B}$ & $\mathbf{p}$ \\
\hline \multirow{3}{*}{$\begin{array}{l}\text { Bağımsız } \\
\text { Değişken }\end{array}$} & 128 & 124 & 32,839 & 000 & & & & \\
\hline & Sabit & & & & 4,190 & 21,712 & & ,000 \\
\hline & Örgütsel & tres & & &,- 345 & $-5,731$ &,- 358 & ,000 \\
\hline \multicolumn{5}{|c|}{ Model Özeti } & \multicolumn{4}{|c|}{ Katsayılar } \\
\hline & \multicolumn{8}{|c|}{ Bağımlı Değişken: Devam Bağlılığı } \\
\hline & $\mathbf{R}^{2}$ & Düz. $\mathbf{R}^{2}$ & $\mathbf{F}$ & $\mathbf{p}$ & B & $\mathrm{T}$ & B & p \\
\hline \multirow{3}{*}{$\begin{array}{l}\text { Bağımsız } \\
\text { Değişken }\end{array}$} & ,070 & ,066 & 16,833 &, 000 & & & & \\
\hline & Sabit & & & & 3,830 & 22,544 & & 000 \\
\hline & Örgütsel & tres & & &,- 217 & $-4,103$ &,- 264 & ,000 \\
\hline \multicolumn{5}{|c|}{ Model Özeti } & \multicolumn{4}{|c|}{$\begin{array}{r}\text { Katsayılar } \\
\end{array}$} \\
\hline & \multicolumn{8}{|c|}{ Bağımlı Değişken: Normatif Bağlılık } \\
\hline & $\mathbf{R}^{2}$ & Düz. $R^{2}$ & F & p & B & $T$ & B & p \\
\hline \multirow{3}{*}{$\begin{array}{l}\text { Bağımsız } \\
\text { Değişken }\end{array}$} & ,065 & ,061 & 15,553 & , 000 & & & & \\
\hline & Sabit & & & & 3,530 & 17,338 & & ,000 \\
\hline & Örgütsel & tres & & &,- 250 & $-3,944$ &,- 255 & ,000 \\
\hline \multicolumn{5}{|c|}{ Model Özeti } & \multicolumn{4}{|c|}{ Katsayılar } \\
\hline & \multicolumn{8}{|c|}{ Bağımlı Değişken: Örgütsel Bağlılık } \\
\hline & $\mathbf{R}^{2}$ & Düz. $R^{2}$ & F & $\mathrm{p}$ & B & $\mathrm{T}$ & B & $\mathrm{p}$ \\
\hline \multirow{3}{*}{$\begin{array}{l}\text { Bağımsız } \\
\text { Değişken }\end{array}$} & , 143 & 140 & 37,495 & 000 & & & & \\
\hline & Sabit & & & & 3,849 & 27,418 & & 000 \\
\hline & Örgütsel & tres & & &,- 268 & $-6,123$ &,- 379 & 000 \\
\hline
\end{tabular}

Kurulmuş olan regresyon modellerine göre örgütsel stresin duygusal, devam ve normatif bağlılık üzerinde anlamlı ve negatif yönde bir etkiye 
sahip olduğu gözlemlenmiştir. Ayrıca örgütsel stresin örgütsel bağl1lı̆̆ genel olarak olumsuz etkilediği bulunmuştur. Öğrenilmiş güçlülüğün örgütsel bağlılık ve alt boyutları üzerindeki etkisini ortaya koyan analiz bulguları Tablo 8' de görülebilmektedir

Tablo 8. Öğrenilmiş Güçlülük ve Örgütsel Bă̆hlık İlişkisine Yönelik Regresyon Analizleri

\begin{tabular}{|c|c|c|c|c|c|c|c|c|}
\hline \multicolumn{5}{|c|}{ Model Özeti } & \multicolumn{4}{|c|}{ Katsayılar } \\
\hline & \multicolumn{8}{|c|}{ Bağımlı Değişken: Duygusal Bağlılık } \\
\hline & $\mathbf{R}^{2}$ & Düz. $\mathbf{R}^{2}$ & F & $\mathrm{p}$ & B & $\mathrm{T}$ & B & $\mathbf{P}$ \\
\hline \multirow{3}{*}{$\begin{array}{l}\text { Bağımsız } \\
\text { Değişken }\end{array}$} & ,214 & 210 & 60,967 & 000 & & & & \\
\hline & Sabit & & & & 1,343 & 5,712 & & ,000 \\
\hline & Öğrenilm & Güçlülük & & &, 596 & 7,808 & ,463 & ,000 \\
\hline \multicolumn{5}{|c|}{ Model Özeti } & \multicolumn{4}{|c|}{ Katsayılar } \\
\hline & \multicolumn{8}{|c|}{ Bağımlı Değişken: Devam Bağlılığı } \\
\hline & $\mathbf{R}^{2}$ & Düz. $\mathbf{R}^{2}$ & F & $\mathrm{p}$ & B & $\mathrm{T}$ & B & $\mathbf{P}$ \\
\hline \multirow{3}{*}{$\begin{array}{l}\text { Bağımsız } \\
\text { Değişken }\end{array}$} & ,161 & 157 & 42,953 & 000 & & & & \\
\hline & Sabit & & & & 1,841 & 8,888 & & ,000 \\
\hline & Öğrenilm & Güçlülük & & & 441 & 6,554 & ,401 & ,000 \\
\hline \multicolumn{5}{|c|}{ Model Özeti } & \multicolumn{4}{|c|}{ Katsayılar } \\
\hline & \multicolumn{8}{|c|}{ Bağımlı Değişken: Normatif Bağlılık } \\
\hline & $\mathbf{R}^{2}$ & Düz. $\mathbf{R}^{2}$ & $\mathbf{F}$ & $\mathbf{p}$ & B & $\mathrm{T}$ & B & $\mathbf{P}$ \\
\hline \multirow{3}{*}{$\begin{array}{l}\text { Bağımsız } \\
\text { Değişken }\end{array}$} & , 180 & 177 & 49,246 & ,000 & & & & \\
\hline & Sabit & & & & 1,089 & 4,451 & & 000 \\
\hline & Öğrenilm & Güçlülük & & & ,558 & 7,018 & ,425 & 000 \\
\hline \multicolumn{5}{|c|}{ Model Özeti } & \multicolumn{4}{|c|}{ Katsayılar } \\
\hline & \multicolumn{8}{|c|}{ Bağımlı Değişken: Örgütsel Bağlılık } \\
\hline & $\mathbf{R}^{2}$ & Düz. $\mathbf{R}^{2}$ & $\mathbf{F}$ & p & B & $\mathbf{T}$ & B & $\mathbf{P}$ \\
\hline \multirow{3}{*}{$\begin{array}{l}\text { Bağımsız } \\
\text { Değişken }\end{array}$} & 310 & 307 & 100,620 & , 000 & & & & \\
\hline & \multirow{2}{*}{\multicolumn{4}{|c|}{$\begin{array}{l}\text { Sabit } \\
\text { Öğrenilmiş Güçlülük }\end{array}$}} & 1,446 & 8,944 & & ,000 \\
\hline & & & & & ,527 & 10,031 &, 557 & ,000 \\
\hline
\end{tabular}

Tablo 8'e göre öğrenilmiş güçlülük duygusal, devam ve normatif bağlılık üzerinde anlamlı ve pozitif yönde bir etkiye sahiptir. Ayrıca öğrenilmiş güçlülüğün örgütsel bağl1lı̆̆ genel olarak olumlu etkilediği de tespit edilmiştir. Öğrenilmiş güçlülüğün örgütsel stres üzerindeki etkisi ise Tablo 9'da görülmektedir. 
Tablo 9. Öğrenilmiş Güçlülük ve Örgütsel Stres İlişkisine Yönelik Regresyon Analizleri

\begin{tabular}{|c|c|c|c|c|c|c|c|c|}
\hline & Mod & 1 Özeti & & & & Katsa & ylar & \\
\hline & & $\mathrm{Ba}$ & $1 \mathrm{ml1} \mathrm{D}$ & fişkeı & Örgüts & 1 Stres & & \\
\hline & $\mathbf{R}^{2}$ & Düz. $\mathbf{R}^{2}$ & $\mathbf{F}$ & $\mathrm{p}$ & B & $\mathrm{T}$ & $\beta$ & p \\
\hline & ,039 & ,035 & 9,122 & ,003 & & & & \\
\hline Bagims1z & Sabit & & & & 3,864 & 14,324 & & , 000 \\
\hline Degişкепाer & Öğrenilm & ş Güçlülül & & &,- 265 & $-3,020$ &,- 198 & ,003 \\
\hline
\end{tabular}

Yapılmış olan regresyon analizinde öğrenilmiş güçlülüğün örgütsel strese etkisi analiz edilmiştir. Ortaya çıkan bulgular öğrenilmiş güçlülüğün örgütsel stresi negatif etkilediğine kanıt sağlamaktadır.

\section{Sonuç, Tartışma ve Öneri}

Örgütsel stres, örgütsel bağlllık, öğrenilmiş güçlülük ilişkisini tespit etmeyi amaçlayan bu çalışmada, öğrenilmiş güçlülük becerisini geliştirilerek çalışanlar üzerindeki stresin azalacağı ve bununla birlikte örgütsel bağlılığın artacağı düşünülmektedir. Bugüne kadar yapılan araştırmalarda; her ülkede stres faktörleri ve stresin yoğun yaşandığı meslekler farklı olmasına rağmen yüksek öğrenilmiş güçlülük düzeyine sahip olanların stresle kolay başa çıkabildikleri tespit edilmiştir.

Araştırma kapsamında yapılan korelasyon analiz sonucuna bakıldığında; örgütsel stres ile örgütsel bağlılık, örgütsel bağlılığın alt boyutları (duygusal, normatif ve devam bağl1lığı) ve öğrenilmiş güçlülük arasında negatif yönde anlamlı ilişki olduğu tespit edilmiştir. Örgütsel bağlılık, örgütsel bağlılığın alt boyutları ve öğrenilmiş güçlülük arasında ise; pozitif yönde anlamlı ilişki olduğu tespit edilmiştir.

Yapılan regresyon analizleri sonucunda; örgütsel stresin örgütsel bağlılık ve bağlılığın alt boyutları olan duygusal bağlılık, devam bağl1lı̆̆1 ile normatif bağlılık boyutlarına negatif yönde anlamlı bir etkisi olduğu sonucuna ulaşılmıştır. Örgütsel stresin örgütsel bağlılık üzerindeki etkisi ile ilgili olarak literatüre bakıldığında bulduğumuz sonuçlarla örtüşen bazı araştırmaların olduğu görülmektedir. Bateman ve Straasser (1984), örgütsel bağlllık ile iş stresi arasında negatif ilişki; Jamal ve Baba (2000), iş stresinin örgütsel bağlılıkla anlamlı ve negatif ilişkisi; Meyer vd. (2002), 
duygusal bağlllık ile stres arasında negatif ilişki; Güçlü (2006), örgütsel stes ile duygusal ve normatif bağlılık arasında negatif yönlü ilişki; Viljoen veRothmann (2009). Örgütsel bağlllık ile iş stresi arasında negatif ilişki; Bhatti vd. (2016), örgütsel bağlllık ile iş stresi arasında negatif ve anlamlı ilişki tespit etmişlerdir. Araştırma görevlileri ve öğretim görevlileri açısından araştırmanın sonucuna bakıldığında, katılımcıların örgütsel stres düzeyleri arttıkça; örgütsel bağlllıklarının, duygusal, devam ve normatif bağlılıklarının azaldığı görülmüştür.

Yapılan diğer regresyon analizleri sonucunda; öğrenilmiş güçlülüğün duygusal bağl1lık, devam bağlılığı ve normatif bağl1lık boyutları üzerinde pozitif yönde anlamlı etkisi olduğu bulunmuştur. Yapılan literatür taramasında örgütsel bağlılık ve öğrenilmiş güçlülük ilişkisini araştıran sadece bir tane çalışmaya rastlanmıştır. Bu çalışmada; Çınar vd. (2016) örgütsel bağl1lık düzeylerinin duygusal anlamda öğrenilmiş güçlülük ile ilişkili olduğunu ve bu ilişkinin yüksek olduğunu tespit etmişlerdir. Bu anlamda elde edilen sonuç literatüre katkı sağlaması açısından önemlidir. Araştırma görevlileri ve öğretim görevlileri açısından elde edilen sonuca bakıldığında, katılımcıların öğrenilmiş güçlülükleri arttığında örgütsel bağl1lık ve örgütsel bağlılık alt boyutlarının arttığı görülmüştür.

Son olarak öğrenilmiş güçlülüğün örgütsel strese etksisidne yönelik yapılan regresyon analizleri sonucunda; öğrenilmiş güçlülüğün örgütsel strese negatif yönde anlamlı etkisi olduğu tespit edilmiştir. Kennet ve Keefer (2006); Akgün ve Ciarrochi (2003) ve Çetin (2018), öğrenilmiş güçlülük ve örgütsel stres araında negatif yönde anlamlı ilişki olduğunu ifade eden digger araştırmacılardır. Araştırma görevlileri ve öğretim görevlileri açısından araştırmanın sonucuna bakıldığında, katılımcıların öğrenilmiş güçlülükleri arttı̆̆ında örgütsel streslerinin azaldığı görülmüştür.

Araştırma görevlileri ve öğretim görevlilerinin; iş yüklerinin (ders saati, araştırma bilimsel araştırmaya zaman ayırma, makale yazma gibi) fazla olması, unvan elde etmede yaşadıkları sıkıntılar, araştırmalar için araç/gereç teminindeki sıkıntıları, ücret yetersizliği, gece öğretim derslerinin verilmesi, yoğunluktan aile, arkadaş ve sosyal yaşama vakit ayıramaması gibi sorunlarla karşı karşıya kalmaları gibi strese neden olan faktörlerinin belirlenip, yetkilikler tarafından düzenlemeler yapılması gerekmektedir (Korkut vd., 1999; Bakioğu ve Yaman, 2004; Alkan vd., 2014). 
Akademik unvan kazanma yollarının açılması, iş kaybetme korkusunun azaltılması, iş yükünü azaltıp daha fazla araştırma yapma imkânı sağlanması, ücretlerin iyileştirilmesi gibi düzenlemeler yapıldığı taktirde stres düzeylerini azalabileceği düşünülmektedir. Diğer bir yandan olayları ve davranışlarını kontrol edebilmeleri için öğrenilmiş güçlülük becerilerinin geliştirilmesi stres kaynaklarıyla başa çıkabilmede kolaylık sağlayacaktır. Böylece kendi kontrol becerilerini kullanarak performanslarında stres verici olayların olumsuz etkilerini asgari düzeye indirmiş olacaklardır. Bu konuda çalışanların eğitim alması veya uzmandan destek alması sağlanabilir. Ortaya çıkan araştırma sonuçlarına göre araştırma görevlileri ve öğretim görevlilerinin, örgütsel stresin olumsuz etkilerinden korunmak, psikolojik sorunların engellenmesi ve örgütsel bağlılığın sağlanması için öğrenilmiş güçlülük becerisi kullanmanın etkili bir yöntem olacağı düşünülebilir.

Bu çalışma araştırma görevlileri ve öğretim görevlileri üzerinde örgütsel stres, örgütsel bağlllık ve öğrenilmiş güçlülük kavramları ile sınırlandırılmıştır. Ayrıca öğrenilmiş güçlülük üzerine yapılan çalışmaların azlığı stres ve bağlılık başta olmak üzere diğer örgütsel davranış konuları gibi teorik alt yapıya oturtulmasını güçleştirdiğinden bu durum hem bir kısıt hem de çalışmanın yazına bir katkısı olarak ifade edilebilir. Bu bağlamda bundan sonra yapılacak olan araştırmalarda farklı iş kollarına veya mesleklere (özellikle de yoğun stres altında olan meslek/iş kollarına) yönelik çalışılabilir. Ek olarak, kâr amacı güden örgütlerde çalışanların öğrenilmiş güçlülük düzeylerini nasıl arttırdıklarına, stresle nasıl baş ettiklerine ve diğer işletmelerle öğrenilmiş güçlülük sayesinde rekabet üstünlügünün nasıl sağlanabileceğine dair çözüm önerili yaklaşımlar geliştirilerek daha farklı çalışmalar yürütülebilir. 


\title{
EXTENDED ABSTRACT
}

\section{An Investigation of The Relationships between Organizational Stress, Organizational Commitment and Learned Resourcefulness}

\author{
Hande Bilgili - Erol Tekin
}

Kastamonu University

The aim of this study is to examine the relationship between organizational stress, learned resourcefulness and organizational commitment in terms of research assistants and academicians, who are among the important stakeholders of the university community. Considering the literature review, it is seen both in domestic and foreign literature that the relationship between organizational stress and organizational commitment has been researched (e.g., Bateman and Strasser,1984; Y1lmaz and Ekici, 2003; Gül et al., 2008; Viljoen and Rothmann, 2009; Şahin, 2014; Bhatti et al., 2016). Similarly, it is seen that there are some studies, which have been encountered in recent years, focusing on the relationship between learned resourcefulness and organizational stress (e.g., Rosenbaum and Cohen, 1999; Akgün and Ciarrochi, 2003; Kennett and Keefer, 2006; Yıldırım et al., 2012; Çetin, 2018). However, it can be said that the relationship between learned resourcefulness and organizational commitment, which has recently been attention-grabbing as a topic, were studied in fewer studies. (e.g., Çınar et al., 2016).

In the context of literature, it can be seen that organizational stress affects organizational commitment negatively. On the other hand, the following hypotheses have been developed based on the idea that learned resourcefulness can both reduce organizational stress by affecting it negatively and increase organizational commitment.

- $H_{1}$ : Organizational stress affects organizational commitment and its sub-dimensions ( $H_{1 a}$ : affective commitment; $H_{1 b}$ : continuance commitment; $H_{1 c:}$ normative commitment). 
- $H_{2}$ : Learned resourcefulness affects organizational commitment and its sub-dimensions ( $H_{2 a}$ : affective commitment; $H_{2 b}$ : continuance commitment; $H_{2 c}$ : normative commitment).

- $H_{3}$ : Learned resourcefulness affects organizational stress.

The population of the research consists of research assistants and academicians working in public universities of the Black Sea Region. A total of 226 questionnaires filled completely were obtained after data collection. In this context, the sampling of the study is comprised of 226 teaching members in total, including 163 research assistants and 63 academicians. To determine the work stress levels of employees, the 10-item scale of work stress scale, which was developed by Suzanne Haynes by applying it on the women and men working in National Health Statistics Center and adapted by Aktaş (1996). To determine the levels of organizational commitment, the questionnaire developed by Allen and Meyer (1990) and adapted for academicians by Tekin and Birincioğlu (2017a) was used. To determine the employees' levels of learned resourcefulness, the 36-item learned resourcefulness scale, which was developed by Rosenbaum (1980) and adapted to Turkish by Siva (1991) and Dağ (1991), was used. All questionnaires were prepared in 5-point Likert type. The obtained data were analyzed via SPSS 23.0. Correlation and regression analyses were used together with factor analyses for the analysis of the data. The results of the factor analyses regarding the scales used in the research are summarized in Table 1, Table 2 and Table 3.

Tablo 1. Factor Analysis of Organizational Stress Scale

\begin{tabular}{lc}
\hline Organizational Stress Scale $(\boldsymbol{\alpha = 0 , 9 3 0 ) ; ~ T o t a l ~ V a r i a n c e : ~}(\% \mathbf{6 1 , 7 8 6 ) ;}$ KMO: $(\mathbf{0 , 8 6 5 )}$ & \\
\hline Question 1 &, 850 \\
Question 2 &, 803 \\
Question 3 &, 804 \\
Question 4 &, 774 \\
Question 5 &, 746 \\
Question 6 &, 842 \\
Question 7 &, 816 \\
Question 8 &, 800 \\
Question 9 &, 628 \\
Question 10 &, 774 \\
\hline
\end{tabular}


In Table 1, the organizational stress scale was summoned under one factor, explaining $61.786 \%$ of the total variance. The $\alpha$ value which appears as a result of the reliability analyses of the overall scale is 0.930 . According to these findings, it can be stated that the scale is reliable.

Tablo 2. Factor Analysis of Organizational Commitment Scale

\begin{tabular}{|c|c|}
\hline \multicolumn{2}{|c|}{ Organizational Commitment Scale $(\alpha=0,881)$;Total Variance: $(\% 58,906) ;$ KMO: $(0,865)$} \\
\hline Affective Commitment: $(\alpha=0,890)$; Variance: $(\% 22,930)$ & Factor Loading \\
\hline Question 1 & ,714 \\
\hline Question 2 & 772 \\
\hline Question 3 & ,836 \\
\hline Question 4 & ,823 \\
\hline Question 5 & 636 \\
\hline Question 6 & 736 \\
\hline Continuance Commitment: $(\alpha=0,874)$; Variance: $(\% 20,868)$ & Factor Loading \\
\hline Question 7 & 645 \\
\hline Question 8 & 752 \\
\hline Question 9 & ,795 \\
\hline Question 10 & 713 \\
\hline Question 11 & 696 \\
\hline Question 12 & ,780 \\
\hline Normative Commitment: $(\alpha=0,747)$; Variance: $(\% 15,107)$ & Factor Loading \\
\hline Question 14 & 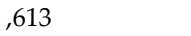 \\
\hline Question 15 & 641 \\
\hline Question 16 & 711 \\
\hline Question 17 & 689 \\
\hline Question 18 & ,584 \\
\hline Question 19 & 709 \\
\hline
\end{tabular}

As it is seen in Table 2, the questions about the organizational commitment scale were gathered under 3 dimensions. These dimensions are expressed as affective commitment, continuance commitment and normative commitment. The 13th question in the original scale, which appears under continuance commitment, was removed from the scale as a result of the factor analysis. In the final version, the scale consists of 18 questions in total including 6 questions about continuance commitment, 6 questions about affective commitment and 6 questions about normative commitment. It is seen that the factor loads related to normative commitment varied between 0.584 and 0.711 ; the factor loads related to the dimension of continuance commitment ranged between 0.645 and 0.795 and the factor loads related to the dimension of affective commitment changed between 0.636 and 0.836 . In addition, the organizational commitment scale, which 
consists of 3 dimensions, explains $58.906 \%$ of the total variance. Besides, it was found that $\alpha$ values which were obtained as a result of reliability analyses were 0.890 in the dimension of affective commitment, 0.874 in the dimension of continuance commitment and 0.747 in the dimension of normative commitment. It can be stated that the overall value of the scale is 0.881 . These results are important in terms of showing high reliability of the scale and its sub-dimensions.

Tablo 3. Factor Analysis of Learned Resourcefulness Scale

\begin{tabular}{|c|c|}
\hline \multicolumn{2}{|c|}{ Learned Resourcefulness Scale $(\alpha=0,935)$; Total Varience: $(\%$ 80,203); KMO=(0,905) } \\
\hline Impulse Control: $(\alpha=0,845) ;$ Variance: $(\% 9,700)$ & Factor Loading \\
\hline Question 1 & 714 \\
\hline Question 2 &, 820 \\
\hline Question 3 &, 709 \\
\hline Competence: $(\alpha=0,873)$; Variance: $(\% 8,844)$ & Factor Loading \\
\hline Question 4 & 818 \\
\hline Question 5 &, 763 \\
\hline Question 6 & 666 \\
\hline Supervisory Research: $(\alpha=0,795)$; Variance: $(\% 8,824)$ & Factor Loading \\
\hline Question 7 & 698 \\
\hline Question 8 & 806 \\
\hline Question 9 &, 845 \\
\hline Appeasement: $(\alpha=0,755)$; Variance: $(\% 8,478)$ & Factor Loading \\
\hline Question 10 & 611 \\
\hline Question 11 &, 764 \\
\hline Question 12 &, 515 \\
\hline Favorable Interpretation: $(\alpha=0,871)$; Variance: $(\% 7,738)$ & Factor Loading \\
\hline Question 13 & 682 \\
\hline Question 14 & 490 \\
\hline Question 15 &, 587 \\
\hline Question 16 & ,724 \\
\hline Mood Control: $(\alpha=0,896)$; Variance: $(\% 7,373)$ & Factor Loading \\
\hline Question 17 & 729 \\
\hline Question18 &, 884 \\
\hline Question 19 & 864 \\
\hline Planned Behavior: $(\alpha=0,828)$; Variance: $(\% 7,321)$ & Factor Loading \\
\hline Question 20 & ,533 \\
\hline Question 21 & 822 \\
\hline Question 22 & ,789 \\
\hline Procrastination: $(\alpha=0,837)$; Variance: $(\% 6,269)$ & Factor Loading \\
\hline Question 23 & 686 \\
\hline Question 24 &, 761 \\
\hline Question 25 & 606 \\
\hline Pain Control: $(\alpha=0,823)$; Variance: $(\% 6,006)$ & Factor Loading \\
\hline Question 26 & 829 \\
\hline Question 27 & 677 \\
\hline
\end{tabular}




\begin{tabular}{ll}
\hline Seeking Help: $(\boldsymbol{\alpha = 0 , 7 4 8 )}$; Variance: $\mathbf{( \% \mathbf { 5 } , \mathbf { 7 0 5 } )}$ & Factor Loading \\
\hline Question 28 &, 878 \\
Question 29 &, 836 \\
\hline Unwanted Thought Control: $(\boldsymbol{\alpha}=\mathbf{0 , 5 3 2 )}$; Variance: $(\mathbf{\%} \mathbf{3 , 9 4 5 )}$ & Factor Loading \\
\hline Question 30 &, 816 \\
Question 31 &, 520 \\
\hline
\end{tabular}

According to Table 3, the sub-dimensions formed in the study differed from the study performed by Dağ (1991). In this study, 11 sub-dimensions were found. The resulting dimensions are similar to those in the study of Kartal and Gemlik (2018). These dimensions are impulse control, competence, supervisory search, appeasement, favorable interpretation, mood control, planned behavior, procrastination, pain control, unwanted thought control, seeking help, and no sub-factors were used in this study; the whole scale was evaluated considering the literature (Biricik, 2018; Akdeniz, 2018; Çetin, 2018). The $\alpha$ value which appears as a result of the reliability analyses of the overall scale is 0.930 . From the related items in the resourcefulness scale, questions $28,29,8,30,31,7,9,12$ and 23 in the study were scored reversely and questions $32,33,34,35$ and 36 were removed from the learned resourcefulness scale.

The normality distribution was reviewed before the analysis of the variables. Especially in social sciences, the assumption of normality can be examined by looking at the skewness and kurtosis coefficients. According to George and Mallery (2010), skewness and kurtosis values in the range of -2 to +2 indicate that the data are normally distributed. In this case, it can be said that the data comply with the normal distribution. Pearson's correlation coefficients were used to see the relationships between the variables used in the study and the findings are presented in Table 4.

Tablo 4. Correlation Analysis

\begin{tabular}{lcccccr}
\hline & OS & AC & CC & NC & OC & LR \\
\hline OS & 1.000 & & & & & \\
AC &,$- 358^{* *}$ & 1.000 & & & & \\
CC &,$- 264^{* *}$ &, $287^{* *}$ & 1.000 & & & \\
NC &,$- 255^{* *}$ &, $613^{* *}$ &, $274^{* *}$ & 1.000 & & \\
OC &,$- 379^{* *}$ &, $822^{* *}$ &, $672^{* *}$ &, $819^{* *}$ & 1.000 & \\
LR &,$- 198^{* *}$ &, $463^{* *}$ &, $401^{* *}$ &, $425^{* *}$ &, $557^{* *}$ & 1,000 \\
\hline
\end{tabular}


Table 6 presents the analysis findings that reveal the effect of organizational stress on organizational commitment and its sub-dimensions.

Tablo 6. Relationship between Organizational Stress and Organizational Commitment Regression Analysis

\begin{tabular}{|c|c|c|c|c|c|c|c|c|}
\hline \multicolumn{5}{|c|}{ Modal Summary } & \multicolumn{4}{|c|}{ Coefficients } \\
\hline & \multicolumn{8}{|c|}{ Dependent Variable: Affective Commitment } \\
\hline & $\mathbf{R}^{2}$ & Düz. $\mathbf{R}^{2}$ & $\mathbf{F}$ & $\mathbf{P}$ & B & $\mathrm{T}$ & B & $\mathbf{P}$ \\
\hline & 128 & 124 & 32,839 & 000 & & & & \\
\hline \multirow[t]{2}{*}{ Independent Variable } & Constant & & & & 4,190 & 21,712 & & , 000 \\
\hline & Organiza & tional Stre & & &,- 345 & $-5,731$ &,- 358 & 000 \\
\hline \multicolumn{5}{|c|}{ Modal Summary } & \multicolumn{4}{|c|}{ Coefficients } \\
\hline & \multicolumn{8}{|c|}{ Dependent Variable: Continuance Commitment } \\
\hline & $\mathbf{R}^{2}$ & Adj. $R^{2}$ & $\mathbf{F}$ & $\mathbf{P}$ & B & $\mathrm{T}$ & B & $\mathbf{P}$ \\
\hline \multirow{3}{*}{ Independent Variable } & ,070 & ,066 & 16,833 & 000 & & & & \\
\hline & Constant & & & & 3,830 & 22,544 & & , 000 \\
\hline & Organiza & tional Stre & & &,- 217 & $-4,103$ &,- 264 & ,000 \\
\hline \multicolumn{5}{|c|}{ Modal Summary } & \multicolumn{4}{|c|}{ Coefficients } \\
\hline & \multicolumn{8}{|c|}{ Dependent Variable: Normative Commitment } \\
\hline & $\mathbf{R}^{2}$ & Adj. $R^{2}$ & $\mathbf{F}$ & $\mathbf{P}$ & B & $\mathbf{T}$ & $\mathbf{B}$ & $\mathbf{P}$ \\
\hline \multirow{3}{*}{ Independent Variable } &, 065 & 061 & 15,553 & 000 & & & & \\
\hline & Constant & & & & 3,530 & 17,338 & & , 000 \\
\hline & Organiza & tional Stre & & &,- 250 & $-3,944$ &,- 255 & ,000 \\
\hline \multicolumn{5}{|c|}{ Modal Summary } & \multicolumn{4}{|c|}{\begin{tabular}{|c|} 
Coefficients \\
\end{tabular}} \\
\hline & \multicolumn{8}{|c|}{ Dependent Variable: Organizational Commitment } \\
\hline & $\mathbf{R}^{2}$ & Adj. $R^{2}$ & $\mathbf{F}$ & $\mathbf{P}$ & B & $\mathrm{T}$ & B & $\mathbf{P}$ \\
\hline \multirow{3}{*}{ Independent Variable } & ,143 & 140 & 37,495 & , 000 & & & & \\
\hline & Constant & & & & 3,849 & 27,418 & & ,000 \\
\hline & Organiza & tional Stre & & &,- 268 & $-6,123$ &,- 379 & 000 \\
\hline
\end{tabular}

According to the established regression models, organizational stress was observed to have a significant and negative effect on affective, continuance and normative commitments. Besides, organizational stress was found to negatively affect organizational commitment in general. The analysis findings revealing the effect of learned resourcefulness on organizational commitment and its sub-dimensions can be seen in Table 7 .

According to Table 7, learned resourcefulness has a significant and positive effect on affective, continuance and normative commitments. Moreover, it was discovered that learned resourcefulness had a positive effect on organizational commitment in general. 
Tablo 7. Relationship between Learned Resourcefulness and Organizational Commitment Regression Analysis

\begin{tabular}{|c|c|c|c|c|c|c|c|c|}
\hline \multicolumn{5}{|c|}{ Modal Summary } & \multicolumn{4}{|c|}{ Coefficients } \\
\hline & \multicolumn{8}{|c|}{ Dependent Variable: Affective Commitment } \\
\hline & $\mathbf{R}^{2}$ & Adj. $R^{2}$ & $\mathbf{F}$ & $\mathbf{P}$ & B & $\mathrm{T}$ & B & $\mathbf{P}$ \\
\hline & ,214 & 210 & 60,967 & 000 & & & & \\
\hline \multirow[t]{2}{*}{ Independent Variable } & Constant & & & & 1,343 & 5,712 & & , 000 \\
\hline & Learned & Resourcef & hess & &, 596 & 7,808 & 463 & ,000 \\
\hline \multicolumn{5}{|c|}{ Modal Summary } & \multicolumn{4}{|c|}{ Coefficients } \\
\hline & \multicolumn{8}{|c|}{ Dependent Variable: Continuance Commitment } \\
\hline & $\mathbf{R}^{2}$ & Adj. $R^{2}$ & $\mathbf{F}$ & $\mathbf{P}$ & B & $\mathrm{T}$ & B & $\mathbf{P}$ \\
\hline \multirow{3}{*}{ Independent Variable } & 161 & 157 & 42,953 & 000 & & & & \\
\hline & Constant & & & & 1,841 & 8,888 & & , 000 \\
\hline & Learned & Resourcef & ness & & 441 & 6,554 & 401 & ,000 \\
\hline \multicolumn{5}{|c|}{ Modal Summary } & \multicolumn{4}{|c|}{ Coefficients } \\
\hline & \multicolumn{8}{|c|}{ Dependent Variable: Normative Commitment } \\
\hline & $\mathbf{R}^{2}$ & Adj. $R^{2}$ & $\mathbf{F}$ & $\mathbf{P}$ & B & $\mathrm{T}$ & B & p \\
\hline \multirow{3}{*}{ Independent Variable } & 180 & ,177 & 49,246 & 000 & & & & \\
\hline & Constant & & & & 1,089 & 4,451 & & ,000 \\
\hline & Learned & Resourcef & ness & &, 558 & 7,018 & 425 & 000 \\
\hline \multicolumn{5}{|c|}{ Modal Summary } & \multicolumn{4}{|c|}{ Coefficients } \\
\hline & \multicolumn{8}{|c|}{ Dependent Variable: Organizational Commitment } \\
\hline & $\mathbf{R}^{2}$ & Adj. $R^{2}$ & F & $\mathbf{P}$ & B & $\mathrm{T}$ & B & p \\
\hline \multirow{3}{*}{ Independent Variable } & ,310 & ,307 & 100,620 & 000 & & & & \\
\hline & Constant & & & & 1,446 & 8,944 & & ,000 \\
\hline & Learned & Resourcef & ness & & ,527 & 10,031 & ,557 & , 000 \\
\hline
\end{tabular}

The effect of learned resourcefulness on organizational stress is given in Table 8. In the regression analysis, the effect of learned resourcefulness on organizational stress was analyzed. The findings provide evidence for the negative effect of learned resourcefulness on organizational stress.

Tablo 8. Relationship between Learned Resourcefulness and Organizational Stress Regression Analysis

\begin{tabular}{|c|c|c|c|c|c|c|c|c|}
\hline \multicolumn{5}{|c|}{ Modal Summary } & \multicolumn{4}{|c|}{ Coefficients } \\
\hline & \multicolumn{8}{|c|}{ Dependent Variable: Organizational Stress } \\
\hline & $\mathbf{R}^{2}$ & Adj. $R^{2}$ & $\mathbf{F}$ & $\mathbf{P}$ & B & $\mathrm{T}$ & B & p \\
\hline \multirow{3}{*}{ Independent Variable } & 039 & ,035 & 9,122 & ,003 & & & & \\
\hline & \multicolumn{4}{|c|}{ Constant } & 3,864 & 14,324 & & , 000 \\
\hline & \multicolumn{4}{|c|}{ Learned Resourcefulness } &,- 265 & $-3,020$ &,- 198 & , 003 \\
\hline
\end{tabular}


It is necessary for the authorized people to determine the factors which causes stress on research assistants and academicians because they encounter problems such as excessive work load (course hours, research, allocating time for scientific research, writing articles etc.), problems with obtaining a title, problems with the supply of equipment for researches, not being able to allocate time for family, friends and social life due to being busy etc., and to do adjustments (Korkut et al., 1999; Bakioğu and Yaman, 2004; Alkan et al., 2014). According to the results of our study, it can be considered that using the learned resourcefulness skill will be an effective method to prevent the negative effects of organizational stress, prevent psychological problems and provide organizational commitment for research assistants and academicians. This study is limited to the concepts of organizational stress, organizational commitment and learned resourcefulness on research assistants and academicians. In addition, since the scarcity of the studies on learned resourcefulness makes it difficult to place other organizational behavior topics, especially stress and commitment on a theoretical infrastructure, this can be expressed both as a limitation and contribution of the study to the literature.

\section{Anket Linki: https://docs.google.com/forms/d/e/1FAIpQLScuWaV- DQqY0J93G_njPOYLwgcmF1-FR59z0vIkjNqjSaqBy8Q/closedform}

\section{Kaynakça / References}

Ağıralioğlu, N. (2012). Türkiye'de üniversitelerin kalitesini belirlemek için bir yaklaşım. Yüksekögretim ve Bilim Dergisi, 2(3), 147-165.

Akgün, S. ve Ciarrochi, J. (2003). Learned resourcefulness moderates the relationship between academic stress and academic performance. Educational Psychology, 23(3), 287-294.

Aktaş, A. M. (2001). Bir kamu kuruluşunun üst düzey yöneticilerinin iş stresi ve kişilik özellikleri. Ankara Üniversitesi SBF Dergisi, 56(4), 25-42.

Alkan, R. M., Suiçmez, M., Aydınkal, M. ve Şahin, M. (2014). Meslek yüksekokullarındaki mevcut durum: Sorunlar ve bazı çözüm önerileri. Journal of Higher Education and Science/Yüksekögretim ve Bilim Dergisi, 4(3), 133-140. 
Allen N. J. ve Meyer, J. P. (1991). A three-component conceptualization of organizational commitment. Human Resource Management Review.1(1), 61-89.

Allen, N. J. ve Meyer, J. P. (1990). The measurement and antecedents of affective, continuance and normative commitment to organizations. Journal of Occupational Psychology, 63, 1-18.

Aydın, İ. (2012). Örgütsel stres kaynakları ve yönetimi: Yozgat Emniyet Müdürlüğü bünyesinde bir uygulama. Yüksek Lisans Tezi, Bozok Üniversitesi, Sosyal Bilimler Enstitüsü, Yozgat.

Bakioğlu, A., ve Yaman, E. (2004). Araştırma görevlilerinin kariyer gelişimleri: Engeller ve çözümler. M.Ü. Atatürk Ĕ̆itim Fakültesi Ĕ̆itim Bilimleri Dergisi, 20, 1-20

Bateman, T. S. ve S. Strasser (1984), A longitudinal of the antecedents of organizational commitment. Academy of Management Journal, 27(1), 95-112.

Bhatti, M. H., Bhatti, M. H., Akram, M. U., Hashim, M. ve Akram, Z. (2016). Relationship between Job Stress and organizational commitment: An empirical study of banking sector. E3 Journal of Business Management and Economics, 7(1), 29-37.

Çakır, A. (2014). Kamu sağlık sektöründe öğrenilmiş güçlülük ile stresle başa çıkma arasındaki ilişki. Doktora Tezi, İstanbul Ticaret Üniversitesi Sosyal Bilimler Enstitüsü, İşletme Anabilim Dalı, İstanbul.

Çetin, B. (2018). Otel işletmelerinde öğrenilmiş güçlülük ve iş stresi ilişkisinde algılanan sosyal desteğin düzenleyicilik rolü: Kapadokya örneği. Doktora Tezi, Mehmet Akif Ersoy Üniversitesi, Sosyal Bilimler Enstitüsü, Nevşehir.

Çınar, F., Şengül, H. ve Koyucu, R. G. (2016). Hastane çalışanlarının öğrenilmiş güçlülük düzeylerinin işten ayrılma niyeti üzerindeki etkisi. Journal of International Social Research, 9(44). 1039-1046.

Çöl, G. (2004). Örgütsel bağlllık kavramı ve benzer kavramlarla ilişkisi. İşgüç Endüstyri İlişkileri ve İnsan Kaynakları Dergisi, 6(2), 20.03.2019 Tarihinde https://www.isguc.org/?p=article\&id=233\&cilt=6\&sayi=2\&yil=2004 adresinden Erişilmiştir.

Dağ, İ. (1991). Rosenbaum'un öğrenilmiş güçlülük ölçeği'nin üniversite öğrencileri için güvenirliği ve geçerliği. Türk Psikiyatri Dergisi, 2, 269-274. 
Doğan, S., ve Kılıç, A. G. S. (2007). Örgütsel bağlllığın sağlanmasında personel güçlendirmenin yeri ve önemi. Erciyes Üniversitesi İktisadi ve İdari Bilimler Fakültesi Dergisi, 29, 37-61.

Efeoğlu, İ, E. ve Özgen, H. (2007). İş-aile yaşam çatişmasinin iş stresi, iş doyumu ve örgütsel bağlilik üzerindeki etkileri: İlaç sektöründe bir araştirma. Çukurova Üniversitesi Sosyal Bilimler Enstitüsü Dergisi, 16(2), 237-254.

George, D. ve Mallery, P. (2010). SPSS for windows step by step:A simple study guide and reference. Boston. Allyn \& Bacon.

Gökdeniz, İ. (2005). Üretim sektöründeki işletmelerin örgüt içi stres kaynaklari ve mobilyacilik sektöründe bir uygulama. Selçuk $\ddot{U} n-$ iversitesi Sosyal Bilimler Enstitüsü Dergisi, 13, 173-189.

Göksel, A. ve Tomruk, Z. (2016). Akademisyenlerde stres kaynakları ile stresle başa çıkmada ve stres durumunda gösterilen davranışların ilişkisi. Türkiye Sosyal Araştırmalar Dergisi, 2, 315-343.

Güçlü, H. (2006). Turizm sektöründe durumsal faktörlerin örgütsel bağhllık üzerindeki etkisi. Eskişehir: Anadolu Üniversitesi Yayınları.

Gül, H., Oktay, E., Gökçe, H. (2008).İ̧s tatmini, stres, örgütsel bağlllık, işten ayrılma niyeti ve performans arasındaki ilişkiler: sağlık sektöründe bir uygulama, Akademik Bakış Uluslararası Hakemli Sosyal Bilimler E Dergisi, 15, 72-82

Gümüştekin, G. E. ve Gültekin, F. (2009). Stres kaynaklarının kariyer yönetimine etkileri. Dumlupınar Üniversitesi Sosyal Bilimler Dergisi, 23(2), 147-158.

Gümüştekin, G. E., ve Öztemiz, A. B. (2005). Örgütlerde stresin verimlilik ve performansla etkileşimi. Çukurova Üniversitesi Sosyal Bilimler Enstitüsü Dergisi, 14(1), 271-288.

Güney, S. (2011). Örgütsel davranış. Ankara: Nobel Yayıncllık.

Işıkhan, V. (2004). Çalışma hayatında stres ve başa çıkma yolları. Ankara: Sandal Yayınları.

Jamal, M., ve Baba, V. V. (2000). Job stress and burnout among canadian managers and nurses: An empirical examination. Can J Public Health, 91(6), 454-58.

Janssen, O. (2004). The barrier effect of conflict with superiors in the relationship between employee empowerment and organizational commitment, Work \& Stress, 18(1), 56-65. 
Kalaycı, Ş. (2010). SPSS uygulamalı çok değişkenli istatistik teknikleri. Ankara:Asil Yayın Dağıtım.

Karataş, S., ve Güleş, H. (2010). İlköğretim okulu öğretmenlerinin iş tatmini ile örgütsel bağllığı arasındaki ilişki. Uşak Üniversitesi Sosyal Bilimler Dergisi, 3(2), 74-89.

Kennett, D. J. ve Keefer, K. (2006). Impact of learned resourcefulness and theories of intelligence on academic achievement of university students: An integrated approach. Educational Pschology, 26(3), 441 457.

Koç, H. (2009).Örgütsel bağl1lık ve sadakat ilişkisi. Elektronik Sosyal Bilimler Dergisi, 8(28), 200-211.

Korkut, H. ve Yalçınkaya, M. (1999). Araştırma görevlilerinin sorunları. Kuram ve Uygulamada Eğitim Yönetimi, 17(17), 19-36.

Korkut, H., Mustan, T., ve Yalçınkaya, M. (1999). Araştırma Görevlilerinin Sorunları. Kuram ve Uygulamada Egitim Yönetimi Dergisi, 5(1), 1936.

Köknel, Ö. (1989). Çağımızın hastahı̆̆ı stres. İstanbul.Milliyet Yayınları.

Meyer, J. P., Stanley, D. J., Herscovitch, L. ve Topolnytsky, L. (2002). Affective, continuance, and normative commitment to the organization: A meta-analysis of antecedents, correlates, and consequences. Journal of Vocational Behavior, 61(1), 20-52.

Öğüt, A., Akgemci, T., ve Demirsel, M. T. (2004). Stratejik insan kaynakları yönetimi bağlamında örgütlerde işgören motivasyonu süreci. Selçuk Üniversitesi Sosyal Bilimler Enstitüsü Dergisi, 12, 277-290.

Onay, M. ve Kılcı, S. (2011). İş stresi ve tükenmişlik duygusunun işten ayrılma niyeti üzerine etkileri: Garsonlar ve aşçıbaşılar. Organizasyon ve Yönetim Bilimleri Dergisi, 3(2), 363-372.

Orloff, J. (2005). Pozitif enerji. İstanbul. Dharma Yayınları.

Özkan, M. S. ve Yıldız, Z. (2015). Öğrenilmiş güçlülük: Kavramsal bir inceleme. Kara Harp Okulu Bilim Dergisi, 25(1), 25-40.

Paşa, M., ve Kaymaz, K. (2013). Stres yönetimi.Bursa: Aktüel Yayıncılar.

Porter, L. W., Steers, R. M., Mowday, R. T., ve Boulian, P. V. (1974). Organizational commitment, job satisfaction and turnover among psychiatric technicians. Journal of Applied Psychology, 59(5), 603-609.

Rosenbaum, M. (1980). A schedule for assessing self-control behaviors: Preliminary findings. Behavior Therapy, 11(1), 109-121. 
Rosenbaum, M. (1980). Individual differences in self-control behaviors and tolerance of painful stimulation. Journal of Abnormal Psychology, 89(4), 581-590.

Rosenbaum, M. (1990). The role of learned resourcefulness in self control health behavior.In (M. Rosenbaum Ed), Learned Resourcefulness: On Coping Skills, Self-Control and Adaptive Behavior, (s.3-30). New York: Springer.

Rosenbaum, M., ve Cohen, E. (1999). Equalitarian marriages, spousal support, resourcefulness, and psychological distress among Israeli working women. Journal of Vocational Behavior, 54(1), 102-113.

Rosenbaum, M., ve Jaffe, Y. (1983). Learned helplessness: The role of individual differences in learned resourcefulness. British Journal of Social Psychology, 22(3), 215-225.

Şahin, B. (2014). Seyahat acentası çalışanlarında örgütsel stresin örgütsel bağlllıkla ilişkisi üzerine bir araştırma: İstanbul örneği. Balıkesir Üniversitesi Sosyal Bilimler Enstitü Dergisi, 17(32), 193-210.

Siva, A. N. (1991). Coping with stress, learned powerfulness, and depression among infertile people. Doctoral Dissertation, Hacettepe University, Ankara.

Tabachnick, B. G. ve Fidell, L. S. (2012). Using multivariate statistics. Boston: Pearson.

Tekin, E. ve Birincioğlu, N. (2017a). araştirma görevlilerinin örgütsel bağlılık düzeylerinin kadro türü ve demografik özellikler açısından incelenmesi. International Journal of Economic $\mathcal{E}$ Administrative Studies, 19, 171-196.

Tekin, E. ve Birincioğlu, N. (2017b). Bilgi çağının odak noktası üniversitelerde mantar yönetimi, International Journal of Academic Value Studies, 3(14), 22-29.

Tiryaki, T. (2005).Örgüt kültürünün örgütsel bağlllık üzerine etkileri. Yüksek Lisans Tezi, Dumlupınar Üniversitesi Sosyal Bilimler Enstitüsü İşletme Anabilim Dalı, Kütahya.

Topaloğlu, M., Koç, H. ve Yavuz, E. (2008). Öğretmenlerin örgütsel bağlılığının bazı temel faktörler açısından analizi. Kamu-İ̧s Dergisi, 9(4), 201-218. 
Üzüm, H., Yalçın, H. B., Özen, G., ve Yüktaşır, B. (2014). Akademik yaşam ve örgütsel stresin kaynakları. Gazi Beden Eğitimi ve Spor Bilimleri Dergisi, 19(1-4), 23-35.

Viljoen, J. P., ve Rothmann, S. (2009). Occupational stress, ill health and organisational commitment of employees at a university of technology. Sa Journal of Industrial Psychology, 35(1), 67-77.

Yazıcıoğlu, İ. ve Topaloğlu, I. G. (2009). Örgütsel adalet ve bağlılık ilişkisi: konaklama işletmelerinde bir uygulama. Isşletme Araştırmaları Dergisi, 1(1), 3-16.

Yıldırım, M. H., Gülpınar, Ş. ve Uğuz, Ş. (2012). İş yaşamında öğrenilmiş güçlülük ile iş stresi arasındaki ilişkileri belirlemeye yönelik bir araştırma. Organizasyon ve Yönetim Bilimleri Dergisi, 4(2), 133-144.

Yıldız, D. (2014). Örgütlerde öğrenilmiş güçlülük kavramı ve insan kaynakları departmanı çalışanlarının öğrenilmiş güçlülük düzeylerinin incelenmesi. Master's Thesis, İstanbul Ticaret Üniversitesi, İstanbul.

Yılmaz, A., ve Ekici, S. (2003). Örgütsel yaşamda stresin kamu çalışanlarının performansına etkileri üzerine bir araştırma. Yönetim ve Ekonomi: Celal Bayar Üniversitesi İktisadi ve İdari Bilimler Fakültesi Dergisi, 10(2), 1-20.

Yılmaz, K., ve Şahin, T. (2017). Eğitim fakültelerindeki araştırma görevlilerinin mesleki deneyimlerinin incelenmesi: araştırma görevlisi olmanın anlamına ilişkin fenomenolojik bir çalışma. Marmara Üniversitesi Atatürk Ĕ̆itim Fakültesi Eğitim Bilimleri Dergisi, 44, 143168.

Yürür, S., ve Keser, A. (2010). Öğrenilmiş güçlülük: Öğretmenler üzerinde bir uygulama. Çalışma İlişkileri Dergisi, 1(1), 59-70.

\section{Kaynakça Bilgisi / Citation Information}

Bilgili, H. ve Tekin, E. (2019). Örgütsel stres, örgütsel bağl1lık ve öğrenilmiş güçlülük ilişkisi üzerine bir araştırma. OPUSUluslararası Toplum Araştırmaları Dergisi, 11(18), 2165-2200. DOI: 10.26466/opus. 557530 